\title{
DESAFIOS DA RESPONSABILIDADE CIVIL NAS RELAÇÕES FAMILIARES: REDES SOCIAIS E OS MÉTODOS ADEQUADOS DE SOLUÇÃO DE CONFLITOS*
}

CHALLENGES OF LIABILITY IN FAMILY RELATIONS: SOCIAL MEDIAS AND ADR'S

\author{
Renata Vilela Multedo ${ }^{1}$
}

RESUMO: O presente artigo pretende abordar a incidência da responsabilidade civil do direito brasileiro nas relações familiares, especificamente na exposição da infidelidade nas redes sociais, pela óptica do descumprimento dos deveres conjugais e convivenciais; bem como os limites da heteronomia dos pais e do Estado no monitoramento dos filhos/alunos nas redes sociais em razão da divulgação de conteúdo íntimo de terceiros e do cyberbullying. Para tanto, pretende-se realizar uma análise dos remédios tradicionais utilizados pela responsabilidade civil, no que tange a reparação dos danos e a resolução dos conflitos familiares e sociais. Sob esse prisma,

\begin{abstract}
This article aims to analyze the incidence of civil liability in the Brazilian law regarding family relations, specifically in the exposition of infidelity in social medias, from the perspective of nonfulfillment of marital and cohabiting duties; as well as the limits of parental and the State's heteronomy in the monitoring of children/students in social media due to the divulgation of intimate third-party content and cyberbullying. The purpose of this study is to pursue whether the traditional instruments used by civil liability, such as repair of damages, have been sufficient and effective in the prevention of injuries and in the resolution of family and social conflicts. Finally, the aproach with the use of the appropriate methods of conflict resolution (ADR's) has been shown to be more adequate for the search of social pacification.
\end{abstract}

1 Doutora e mestre em Direito Civil pela Universidade do Estado do Rio de Janeiro (UERJ). MBA em Administração de Empresas pela PUC-Rio. Professora Titular de Direito Civil do Centro Universitário IBMEC. Professora dos cursos de pós-graduação lato sensu da PUC-Rio. Advogada capacitada e Práticas Colaborativas e Mediadora do Conflitos. Autora de diversos artigos jurídicos e do livro "Liberdade e Família: limites para intervenção do Estado nas relações conjugais e parentais". Rio de Janeiro: Editora Processo, 2017. ORCID n. 0000000166774082.

Este artigo é fruto da palestra conferida nas II Jornadas Luso-Brasileiras de Responsabilidade Civil realizada pela Faculdade de Direito da Universidade de Coimbra nos dias 8 e 9 de novembro de 2018. Agradeço as preciosas contribuições da pesquisadora Beatriz Coelho, graduanda em Direito pela Universidade Federal do Rio de Janeiro (UFRJ) e da Professora Ana Paula Agra, Mestre em Direito Constitucional pela PUC-Rio. 


\section{Revista IBERC}

v. 2, n. 2, p. 01-35, mai.-ago./2019

www.responsabilidadecivil.org

aborda-se como a utilização dos métodos alternativos de resolução de conflitos tem se mostrado mais adequada na busca da pacificação social.

Palavras-chave: Responsabilidade civil. Direito de Família. Infidelidade virtual. Keywords: Civil liability. Family Law. Social Cyberbullying. Métodos adequados de media. Cyberbullying. ADR's. resolução de conflitos.

SUMÁRIO: 1. Introdução. 2. A constitucionalização do direito de família brasileiro. 3. A incidência da responsabilidade civil nas relações familiares e a exposição da infidelidade conjugal no ambiente virtual. 4. A divulgação de imagens e conteúdos íntimos de terceiros e a prática do cyberbullying nas redes sociais por crianças e adolescentes. 5. À guisa de conclusão: os métodos adequados para resolução de conflitos e a busca da construção da paz. 6 . Referências.

\section{INTRODUÇÃO}

Não por acaso a aplicabilidade e a pertinência do instituto da responsabilidade civil às relações familiares ensejam frequentes debates tanto em sede doutrinária como jurisprudencial no Brasil. As transformações ocorridas no âmbito da responsabilidade civil e no direito de família, nas últimas décadas, evidenciam que a questão reclama do intérprete um aprofundamento teórico e interdisciplinar diante da diversidade e multiplicidade de conflitos.

Se o controle sobre as vicissitudes pessoais e familiares só se justifica se e na medida em que for realizado em função da garantia dos direitos fundamentais, ${ }^{2}$ é a proteção desses direitos no interior da família que traz novas consequências tanto às relações conjugais e convivenciais como às parentais. Nas primeiras, a família aponta para a ampliação da autonomia do casal, com a consequente diminuição de normas cogentes; nas segundas, pelo contrário, implica o aumento da responsabilidade no exercício da parentalidade. Ou seja, os movimentos intrafamiliares que podem ser

\footnotetext{
${ }^{2}$ PERLINGIERI, Pietro. O direito civil na legalidade constitucional. Rio de Janeiro: Renovar, 2008. p. 980.
}

Revista IBERC, Minas Gerais, v. 2, n. 2, p. 01-35, mai.-ago./2019 


\section{Revista IBERC}

v. 2, n. 2, p. 01-35, mai.-ago./2019

www.responsabilidadecivil.org

identificados são, de um lado, a forte expansão da autonomia existencial; e de outro, a responsabilização crescente e solidarista no exercício da autoridade parental. ${ }^{3}$

No que tange à responsabilidade civil, diz-se que uma das causas essenciais das constantes e aceleradas transformações deve ser procurada no caráter cada vez mais perigoso da vida contemporânea. De fato, ressalta-se que "desprovidos de segurança material, procuramos de mais a mais a segurança jurídica" ${ }^{4}$

Daí a importância de se delimitar o papel que a responsabilidade civil vem desempenhando na atualidade. Se, por um lado, as conquistas realizadas pelo direito da responsabilidade civil - uma primeira forma de tutela de interesses que se encontram à margem do direito positivado ${ }^{5}$ - conferiram maior proteção à pessoa humana, por outro, a ausência de critérios na concessão dos pedidos de dano moral, possibilitando que qualquer interesse seja associado à dignidade humana para fins de indenização, vem acarretando na própria inversão dos valores constitucionais, ${ }^{6}$ por meio da sua banalização e da mercantilização das relações existenciais.

Tal alerta não vem partindo apenas da doutrina, mas também do próprio Judiciário, que hoje admite grande dificuldade para estabelecer a equivalência entre o dano e a sua compensação, principalmente devido ao aumento exponencial da quantidade de processos com pedidos de indenização por dano moral que "abarrotam", todos os dias, os tribunais brasileiros. ${ }^{7}$

A questão agrava-se, ainda, diante do fenômeno das redes sociais ${ }^{8}$, que transformou a forma de se relacionar dos indivíduos na sociedade contemporânea. $\mathrm{O}$

\footnotetext{
3 BODIN DE MORAES, Maria Celina. A nova família, de novo: estruturas e funções das famílias contemporâneas. Revista Pensar, Fortaleza, v. 18, n. 2, mai./ago. 201, p. 594.

4 JOSSERAND, Louis. Evolução da Responsabilidade Civil. In: Revista Forense, junho/1941. pp. 52-53.

5 RODOTÀ, Stefano. Entrevista. Revista Trimestral de Direito Civil, n. 11, jul.-set. 2002. pp. 287-288.

${ }^{6}$ RODOTÀ, Stefano. Il problema della responsabilità civile. Milano: Giuffrè, 1967. p. 17.

7 STJ busca parâmetros para uniformizar valores de danos morais. Disponível em: https://www.migalhas.com.br/Quentes/17,MI92810,41046-

STJ+busca+parametros+para+uniformizar+valores+de+danos+morais . Acesso em 05 nov. 2108.

${ }^{8}$ Segundo Manuel Castells "As redes sociais digitais baseadas na internet e nas plataformas sem fio são ferramentas decisivas para organizar, mobilizar, deliberar, coordenar e decidir. Mas o papel da internet ultrapassa a instrumentalidade: ela cria as condições para uma forma de prática comum que permite a um movimento sem liderança sobreviver, deliberar, coordenar e expandir-se. Ela protege o movimento da repressão de seus espaços físicos liberados, mantendo a comunicação entre as pessoas dos movimentos e
} 


\section{Revista IBERC}

v. 2, n. 2, p. 01-35, mai.-ago./2019

www.responsabilidadecivil.org

ambiente virtual tem trazido novos desafios para a proteção da privacidade e dignidade das pessoas, o que, paralelamente, caminha com a necessidade de se pensar em novos mecanismos de prevenção, tutela e reparação.

A facilidade com que as pessoas têm acesso a conteúdos íntimos e dados de terceiros ocasionam, frequentemente, violações aos direitos da personalidade. Nos últimos anos, lesões à privacidade, à honra, ao nome e à imagem da pessoa humana veiculados no ambiente virtual vêm aumentando, devido ao fenômeno das redes sociais.

Se é certo que a Internet promoveu a possibilidade jamais antes vista de interatividade por meio de diversos canais (Facebook, WhatsApp, Instagram, YouTube, Twitter, dentre outros), ${ }^{9}$ ela também potencializou os conflitos intrafamiliares e sociais. A "Internet apresenta-se cada vez mais como uma trama de possibilidades ainda não resolvida, como um conjunto de promessas contraditórias". ${ }^{10}$ Liberdade e responsabilidade caminham lado a lado, muitas vezes como interesses opostos e não complementares.

Sob esse prisma, é que se pretende investigar, sob a ótica da doutrina e da jurisprudência brasileiras, a incidência da responsabilidade civil nas relações familiares em razão da utilização das redes sociais, em especial em duas principais situações: a primeira no que tange aos danos causados em razão da exposição da infidelidade conjugal; e a segunda quanto à responsabilidade dos pais, do Estado e dos estabelecimentos escolares nos casos de divulgação de conteúdo íntimo de terceiros e da prática do cyberbullying por crianças e adolescentes nas redes sociais.

com a sociedade em geral na longa marcha da mudança social exigida para superar a dominação institucionalizada". (CASTELLS, Manuel. Redes de indignação e esperança - Movimentos sociais na era da internet. Rio de Janeiro: Jorge Zahar, 2013. p. 141).

${ }^{9}$ No Brasil, a banda larga móvel é a principal forma de conexão para um quarto dos domicílios brasileiros com acesso à Internet e dentre as atividades on-line, as mais mencionadas continuam sendo o envio de mensagens instantâneas e o uso de redes sociais. Pesquisa sobre o uso das tecnologias de informação e comunicação nos domicílios brasileiros: TIC domicílios 2016. Núcleo de Informação e Coordenação do Ponto BR. São Paulo. Comitê Gestor da Internet no Brasil, 2017. p. 26-27. In: TEFFÉ, Chiara. Revista IBERC, Minas Gerais, v. 1, n. 1, pp. 01-28, nov. - fev. 2019, p. 5. Disponível em: https://docs.wixstatic.com/ugd/5d72ed_bab4da105706419dbbbc3804ce8add99.pdf. Acesso em 05 nov. 2108. 10 RODOTÀ, Stefano. A vida na sociedade da vigilância: A privacidade hoje. Organização, seleção e apresentação de Maria Celina Bodin de Moraes. Tradução: Danilo Doneda e Luciana Cabral Doneda. Rio de Janeiro: Renovar, 2008. p. 169. 


\section{Revista IBERC}

v. 2, n. 2, p. 01-35, mai.-ago./2019

www.responsabilidadecivil.org

Como marco teórico, adotou-se no presente estudo a constitucionalização do direito civil, partindo-se das seguintes premissas: 1) o princípio da dignidade humana como regedor de todo o ordenamento jurídico determina que a pessoa passe a ser 0 norte que permite conferir relevância formal e material às relações em que cada indivíduo se encontra e as relações familiares e sociais que o caracterizam; 2) a relatividade e a historicidade dos institutos jurídicos, torna imperioso contextualizar o conceito de família no espaço e no tempo: na realidade brasileira contemporânea; 3) a prevalência da tutela das relações existenciais frente às patrimoniais impõe uma proteção diferenciada em relação à privacidade como autonomia existencial, vista como o direito de autodeterminar-se e de manter o controle sobre as próprias informações; 4) a funcionalização dos institutos jurídicos, tais como a família, o casamento e a responsabilidade civil, passam a só serem merecedores de tutela como instrumentos de realização da dignidade de seus membros; 5) O valor principal a ser perseguido nas relações familiares é a promoção da dignidade da pessoa humana, que só se concretiza nos princípios da liberdade e da igualdade conformados pela solidariedade familiar.

Por fim, pretende-se, ainda, refletir sobre os remédios tradicionais utilizados pela responsabilidade civil, como a indenização em pecúnia, no âmbito das relações de família, bem como analisar a repercussão e eficácia da adoção dos métodos não adversariais de resolução de conflitos como forma mais adequada para tratar das relações familiares e sociais.

\section{A CONSTITUCIONALIZAÇÃO DO DIREITO DE FAMÍLIA BRASILEIRO}

$\mathrm{Na}$ perspectiva contemporânea do direito civil, todas as situações jurídicas subjetivas submetem-se ao controle de merecimento de tutela, com base no projeto constitucional. Uma concepção moderna da família requer, portanto, uma funcionalização do instituto que responda às escolhas de fundo da sociedade contemporânea ${ }^{11}$, operadas

\footnotetext{
${ }^{11}$ PERLINGIERI, Pietro. O direito... p. 138.
} 


\section{Revista IBERC}

v. 2, n. 2, p. 01-35, mai.-ago./2019

www.responsabilidadecivil.org

pela Constituição Federal brasileira (CF). É isso que corrobora a cláusula geral de tutela da pessoa humana e notadamente os artigos $226, \S 5^{\circ}$, que estabeleceu a igualdade dos cônjuges no casamento, e 227 da CF, que atribuiu aos filhos a posição de centralidade no grupo familiar, garantindo concretude ao princípio da igualdade material e "absoluta prioridade" às crianças e aos adolescentes. ${ }^{12}$

Essa concepção implica a rejeição do paradigma, que por muito tempo perdurou, do direito de família como um sistema hermético, que tinha no casamento o centro gravitacional. O fenômeno familiar não é mais unitário, tendo deixado o casamento de servir como referência única. Na passagem da estrutura à função ${ }^{13}$, a família deixou de ser unidade institucional, para tornar-se núcleo de companheirismo ${ }^{14}$, sendo hoje lugar de desenvolvimento da pessoa no qual se permitem modalidades de organização tão diversas, desde que estejam finalizadas à promoção daqueles que a ela pertencem. ${ }^{15}$

A referida função promocional assumida pelo direito nas constituições pósliberais ${ }^{16}$ possibilitou, no âmbito da família, o reconhecimento de novas entidades familiares, plurais, porque deixadas à livre escolha de seus membros e, como dito, tuteladas como instrumento de promoção da dignidade daqueles que a compõem. A axiologia constitucional recente tornou possível a propositura de uma configuração democrática de família, na qual não há direitos sem responsabilidades, nem autoridade sem democracia. ${ }^{17}$

Nesse novo cenário, constata-se que, entre os anos de 1984 e 2007, a taxa de divórcios no Brasil aumentou 200\%, atingindo, segundo as pesquisas estatísticas realizadas pelo IBGE, o seu maior valor em série desde 1984. Isso significa dizer que, para cada quatro casamentos realizados, houve uma dissolução. ${ }^{18}$ A partir de 1989 , também houve um aumento significativo do número de divórcios em decorrência da

\footnotetext{
${ }^{12}$ BODIN DE MORAES, Maria Celina. A nova família... p. 588.

${ }^{13}$ Ver, por todos, BOBBIO, Norberto. Da estrutura à função: novos estudos de teoria do direito. São Paulo: Manole, 2007.

14 VILLELA, João Baptista. Repensando o direito de família. Disponível em: http://jfgontijo.com.br/2008/artigos_pdf/Joao_Baptista_Villela/RepensandoDireito.pdf. Acesso em: 3 fev. 2016.

${ }^{15}$ PERLINGIERI, Pietro. $O$ direito civil... p. 972.

${ }^{16}$ BOBBIO, Norberto. Da estrutura... p. 13.

${ }^{17}$ BODIN DE MORAES, Maria Celina. A nova família... p. 591-593.

18 INSTITUTO BRASILEIRO DE GEOGRAFIA E ESTATÍSTICA. Estatísticas do Registro Civil 2007. Disponível em: http://www.ibge.gov.br/ home/estatistica/populacao/registrocivil/2007/registrocivil 2007.pdf. Acesso em: 07 fev. 2018
} 


\section{Revista IBERC}

v. 2, n. 2, p. 01-35, mai.-ago./2019

www.responsabilidadecivil.org

alteração do parágrafo $6^{\circ}$ do art. 226 da Constituição Federal, que reduziu os prazos mínimos para se iniciarem os processos judiciais. Antes, conforme a Lei do Divórcio (Lei $n^{\circ}$ 6.015, de 1977), eram necessários cinco anos consecutivos de ruptura da vida em comum para o pedido de separação judicial e três anos da separação judicial para sua conversão em divórcio. Com a promulgação da Constituição, o casamento civil podia ser dissolvido pelo divórcio após prévia separação judicial por mais de um ano ou uma vez comprovada separação de fato por mais de dois anos.

Posteriormente, em julho de 2010, a Emenda Constitucional $n^{\circ} 66$ promoveu outra alteração no referido artigo, suprimindo do texto constitucional as referências ao instituto da separação e aos respectivos prazos: com isso, atualmente, é possível requerer a dissolução do casamento a qualquer tempo, seja o divórcio de natureza consensual ou litigiosa. ${ }^{19}$ No mesmo ano, quando realizado o último censo, foram registrados 243.224 divórcios e 67.623 separações, incluindo processos judiciais e escrituras públicas ${ }^{20}$; e, como destacado na pesquisa realizada pelo IBGE, para além da questão legal, esse aumento da taxa de divórcios só demonstra sua aceitação pela

\footnotetext{
${ }^{19}$ Constituição Federal. Art. 226, § 6 $6^{\circ}$ : "O casamento civil pode ser dissolvido pelo divórcio". (Redação dada pela Emenda Constitucional $n^{\circ} 66$ de 2010). Vale mencionar que na jurisprudência, ao mesmo tempo que várias decisões se posicionavam no sentido de que a referida emenda apenas eliminou os requisitos temporais do divórcio, mantendo a separação como forma de dissolução da sociedade conjugal, outras extinguiam os requerimentos de separação judicial por impossibilidade jurídica do pedido. Parte expressiva da doutrina defende que não há mais que se falar na permanência da separação, a exemplo de Rodrigo da Cunha Pereira, que afirma: "O argumento finalístico é que a Constituição da República extirpou totalmente de seu corpo normativo a única referência que se fazia à separação judicial. Portanto, ela não apenas retirou os prazos, mas também o requisito obrigatório ou voluntário da prévia separação judicial ao divórcio por conversão. Qual seria o objetivo de se manter vigente a separação judicial se ela não pode mais ser convertida em divórcio? Não há nenhuma razão prática e lógica para a sua manutenção. Não podemos perder o contexto, a história e o fim social da anterior redação do $\S 6^{\circ}$ do art. 226: converter em divórcio a separação judicial. E, se não se pode mais convertê-la em divórcio, ela perde sua razão lógica de existência". (PEREIRA, Rodrigo da Cunha. O novo divórcio no Brasil. PEREIRA, Rodrigo da Cunha (Coord.). Família e responsabilidade: teoria e prática do direito de família. Porto Alegre: Magister/IBDFAM, 2010. p. 469-470). O novo Código de Processo Civil reacendeu o debate ao expressamente se referir à separação judicial em seu artigo 23, inciso III, e em diversos outros dispositivos. A fim de pacificar a questão, o Superior Tribunal de Justiça, em decisão recente, reafirmou a possibilidade da separação judicial, asseverando que "o texto constitucional dispõe que o casamento civil pode ser dissolvido pelo divórcio, imprimindo faculdade aos cônjuges, e não extinguindo a possibilidade de separação judicial. Ademais, sendo o divórcio permitido sem qualquer restrição, forçoso concluir pela possibilidade da separação ainda subsistente no Código Civil, pois quem pode o mais, pode o menos também". (BRASIL. Superior Tribunal de Justiça. Recurso Especial 1247098/MS. Relator: Ministra Maria Isabel Gallotti. Julgamento: 14.03.2017. Órgão Julgador: Quarta Turma.) ${ }^{20}$ INSTITUTO BRASILEIRO DE GEOGRAFIA E ESTATÍSTICA. Estatísticas do registro civil: 2010. Disponível em: https://ww2.ibge.gov.br/home/estatistica/populacao/registrocivil/2010/default_zip.shtm. Acesso em: 05 set. 2018.
}

Revista IBERC, Minas Gerais, v. 2, n. 2, p. 01-35, mai.-ago./2019 


\section{Revista IBERC}

v. 2, n. 2, p. 01-35, mai.-ago./2019

www.responsabilidadecivil.org

sociedade brasileira, além da desburocratização ${ }^{21}$ e da ampliação do acesso aos serviços de justiça referentes ao assunto.

Além do reconhecimento de entidades familiares diversas do casamento, dentre as diversas alterações operadas pelo texto constitucional no ambiente familiar, destacamse: a equiparação de qualificação de todos os filhos independentemente da origem da filiação (art. 227, $\S 6^{\circ}$ ); a facilitação do divórcio, independentemente de culpa e o planejamento familiar voltado para os princípios da dignidade da pessoa humana e da paternidade responsável (art. $226, \S 7^{\circ}$ ); e a previsão de ostensiva intervenção estatal no núcleo familiar com o fim de proteger seus integrantes e coibir a violência doméstica (art. $\left.226, \S 8^{\circ}\right)$.

Após um longo período de dogmas e preconceitos, a família fundada no casamento, preservada e valorizada a qualquer custo como instituição acima dos interesses de seus integrantes, cede lugar a uma família que passa a ser vista como um núcleo intermediário de desenvolvimento da personalidade dos filhos e de promoção da dignidade de seus membros. Nessa concepção, a família passa a ser garantida pela Constituição "não como portadora de um interesse superior e superindividual, mas, sim, em função da realização das exigências humanas, como lugar onde se desenvolve a pessoa". ${ }^{22}$

Tais transformações atingiram de forma ainda mais incisiva o direito da filiação. Isso porque, além da consagração do princípio da isonomia, que proíbe qualquer forma de discriminação entre os filhos independentemente do modelo de relação existente entre seus pais ${ }^{23}$, alterou-se radicalmente o enfoque das relações parentais, hoje calcadas na responsabilidade e na solidariedade familiar. Diante da atual realidade, torna-se claro que a criança e o adolescente são vistos nas relações parentais como a parte vulnerável e, logo, carecedora de maior proteção. Portanto, justificou-se a atuação do legislador

\footnotetext{
${ }^{21}$ Também foi relevante para o aumento do número de divórcios no Brasil a promulgação da Lei ${ }^{\circ} 11.441$, em 11 de janeiro de 2007, que permitiu aos cônjuges, havendo consensualidade e inexistindo filhos menores ou incapazes, realizarem as separações e os divórcios pela via administrativa, nos Tabelionatos de Notas do País.

${ }^{22}$ PERLINGIERI, Pietro. Perfis do direito civil. Rio de Janeiro: Renovar, 1999. p. 243.

${ }^{23} \mathrm{O}$ art. 227, parágrafo $8^{\circ}$, da CF/88, dispõe: "Os filhos, havidos ou não da relação do casamento, ou por adoção, terão os mesmos direitos e qualificações, proibidas quaisquer designações discriminatórias relativas à filiação".
} 


\section{Revista IBERC}

v. 2, n. 2, p. 01-35, mai.-ago./2019

www.responsabilidadecivil.org

constituinte nas questões atinentes ao direito da filiação, impondo-se mais obrigações aos pais e assegurando-se maior proteção aos filhos. ${ }^{24}$ Ao mesmo tempo, a educação passou a exercer uma função emancipatória ${ }^{25}$, em decorrência da modificação na própria forma de exercício da autoridade parental, hoje concebida como um poder-dever posto no interesse exclusivo do filho e com a finalidade de satisfazer suas necessidades e desenvolvimento de sua autonomia. ${ }^{26}$

No seio da família constitucionalizada, o indivíduo exclusivamente abstrato, considerado de maneira isolada e detentor de direitos patrimoniais, dá lugar ao sujeito concreto, em suas diversas manifestações. ${ }^{27}$ Assim, partindo-se da premissa de que "o ordenamento realmente vigente é o conjunto dos ordenamentos dos casos concretos, como se apresentam na experiência do dia a dia, e vive, portanto, exclusivamente enquanto individualizado e aplicado aos fatos e aos acontecimentos" ${ }^{28}$, é que se pretende analisar a responsabilidade civil nas relações familiares.

\section{A INCIDÊNCIA DA RESPONSABILIDADE CIVIL NAS RELAÇÕES FAMILIARES E A EXPOSIÇÃO DA INFIDELIDADE CONJUGAL NO AMBIENTE VIRTUAL}

A ideia de que os conteúdos da relação íntima conjugal é assunto exclusivo dos nela envolvidos e que "cada casal é seu próprio legislador" supõe que os sistemas jurídicos eliminem progressivamente os conteúdos que outrora serviam a todos, mas que

\footnotetext{
${ }^{24}$ Como esclarece Gustavo Tepedino, "a interferência na esfera jurídica dos filhos só encontra justificativa funcional na formação e no desenvolvimento da personalidade dos próprios filhos, não caracterizando posição de vantagem juridicamente tutelada em favor dos pais" (TEPEDINO, Gustavo. A disciplina da guarda e a autoridade parental na ordem civil-constitucional. Revista Trimestral de Direito Civil, v. 17, n. 5, p. 40-41, jan./mar. 2004). Neste sentido também destaca Giselda Maria Fernandes Novaes Hironaka (Responsabilidade Civil na relação paterno-filial. Anais do III Congresso Brasileiro de Direito de Família: Família e Cidadania - O Novo CCB e a vacatio legis. Belo Horizonte: IBDFAM/Del Rey, 2002. p. 429-430): "A responsabilidade dos pais consiste principalmente em dar oportunidade ao desenvolvimento dos filhos, consiste em ajudá-los na construção o da própria liberdade. Trata-se de uma inversão total, portanto, da ideia antiga e maximamente patriarcal de pátrio poder".

${ }^{25}$ PERLINGIERI, Pietro. O direito... p. 258.

${ }^{26}$ BODIN DE MORAES, Maria Celina. Jurisprudência comentada: deveres parentais e responsabilidade civil. Revista Brasileira de Direito de Família, Porto Alegre, n. 31, p. 55-56, 2005.

${ }^{27}$ FACHIN, Luiz Edson. Teoria crítica do direito civil. Rio de Janeiro: Renovar, 2000. p. 11 e ss.

${ }^{28}$ PERLINGIERI, Pietro. O direito... p. 201.
} 


\section{Revista IBERC}

v. 2, n. 2, p. 01-35, mai.-ago./2019

www.responsabilidadecivil.org

hoje estão sujeitos à negociação, pois os cônjuges e conviventes, que espontaneamente escolheram adentrar uma comunhão de vida, assumem compromissos próprios. ${ }^{29}$

Isso não significa a não incidência da responsabilidade civil nas relações afetivas, mas tão somente que a principal discussão doutrinária delineada se refere à responsabilização pelo mero descumprimento dos deveres conjugais e convivenciais.

De fato, o legislador infraconstitucional brasileiro, seguindo a mesma linha do Código Civil de $1916^{30}$, positivou, no art. 1.566 do Código de $2002^{31}$, os deveres conjugais recíprocos que pautam a relação daqueles que optam pela via do matrimônio, como requisitos para a sua eficácia. Da mesma forma, impôs deveres aos componentes da união estável, consoante 0 art. 1.724 da mesma Lei. ${ }^{32}$ No entanto, desde a modificação promovida pela Emenda Constitucional n ${ }^{\circ} 66$ de 2010 no $\S 6^{\circ}$ do art. 226 da Constituição de 1988, a culpa perdeu relevância para dissolver o vínculo matrimonial, convertendo o divórcio em um direito potestativo (art. 1.580, $\S 1^{\circ}$, do CC). Isso significou um esvaziamento dos efeitos jurídicos dos deveres conjugais no direito de família ${ }^{33}$, os

\footnotetext{
${ }^{29}$ Como indaga Guilherme de Oliveira, nos países que abandonaram o divórcio baseado na culpa, "que relevância jurídica tem a violação de um dever conjugal?". Responde o autor que "o resultado que vem se apurando de tudo isto é o de que da relação entre indivíduos 'que lutam', amando-se, pela realização pessoal, desligados de qualquer quadro de valores e de respostas externas - é o de uma 'relação pura' (referida por Giddens), apenas baseada no compromisso permanente e na gratificação renovada, que contêm em si o acordo prévio sobre a sua dissolução. Trata-se, afinal, [...] de construir relações possíveis, que diariamente tem de julgar e escolher todos os seus passos”. OLIVEIRA, Guilherme de. Queremos amar-nos... mas não sabemos como. Temas de direito da família. Coimbra: Coimbra Editora, 2001. p. 337.

30 "O tratamento dado pelo Código Civil de 1916, e conservado pelo Código Civil de 2002 aos deveres conjugais e às suas consequências no momento da ruptura da relação, revela que houve um prolongamento de seu modo de tratamento, sem um repensar profundo acerca da oportunidade de manutenção da descrição dos deveres conjugais e de seus reflexos na separação judicial” (CARBONERA, Silvana Maria. Reserva de intimidade: uma possível tutela da dignidade no espaço relacional da conjugalidade. Rio de Janeiro: Renovar, 2008. p. 232)

${ }^{31}$ Art. 1.566. São deveres de ambos os cônjuges: I - fidelidade recíproca; II - vida em comum, no domicílio conjugal; III - mútua assistência; IV - sustento, guarda e educação dos filhos; V - respeito e consideração mútuos.

${ }^{32}$ Conforme se depreende do texto legal, são deveres conjugais a "fidelidade recíproca", a "vida em comum no domicílio conjugal", "a mútua assistência", o "sustento, guarda e educação dos filhos" e o "respeito e consideração mútuos".
}

Art. 1.724. As relações pessoais entre os companheiros obedecerão aos deveres de lealdade, respeito e assistência e de guarda, sustento e educação dos filhos.

${ }^{33}$ Há quem sustente que o descumprimento dos deveres conjugais gera o dever de indenizar por parte daquele que os descumpriu. Nesse sentido, TAVARES DA SILVA, Regina Beatriz. Reparação civil na separação e no divórcio. São Paulo: Saraiva, 1999. Em recente decisão, o juiz da $2^{a}$ Vara Cível de Governador Valadares decidiu que uma técnica de enfermagem, traída, deve ser indenizada pelo rompimento de seu casamento dez dias após a cerimônia. O ex-marido e a amante, réus no processo, terão de pagar, conforme a decisão monocrática, $\mathrm{R} \$ 50$ mil por danos morais, já que a situação teria causado "imenso 


\section{Revista IBERC}

v. 2, n. 2, p. 01-35, mai.-ago./2019

www.responsabilidadecivil.org

quais se tornaram meros enunciados morais e não jurídicos ${ }^{34}$, cujo inadimplemento não tem o condão de afetar a existência, a validade ou a eficácia do casamento. ${ }^{35}$

Já os deveres de mútua assistência, de respeito e consideração mútuos e de sustento, guarda e educação dos filhos são admissíveis e exigíveis ${ }^{36}$, pois se coadunam com a ordem constitucional e decorrem diretamente da solidariedade familiar e da responsabilidade parental, aplicáveis às relações familiares como um todo.

Em contrapartida, destaca-se em doutrina que o legislador infraconstitucional, com o objetivo de proteger e de manter o vínculo conjugal, positivou verdadeira intromissão estatal na privacidade dos cônjuges, individual e conjuntamente, sendo um instrumento de cunho moral de controle coercitivo. ${ }^{37}$ Demais a mais, a quebra do dever de fidelidade não impede o reconhecimento da conjugalidade, que deve ser baseada unicamente na vontade livre dos cônjuges de se relacionarem segundo as próprias opções pessoais.

Sob essa perspectiva, afirma Luiz Edson Fachin:

constrangimento, aborrecimento e humilhação" à mulher. Disponível em: http://www.amodireito.com.br/2015/11/ex- marido-e-sua-amante-terao-de.html?m=1. Acesso em: 4. fev. 2016. 34 SILVA, Marcos Alves da. Da monogamia: a sua superação como princípio estruturante do direito de família. Curitiba: Juruá, 2013, p. 317-318, v. 1.

35 "Eventual ou reiterado, dissimulado ou público, o inadimplemento dos deveres conjugais, por um ou ambos os cônjuges, em nada afeta a existência, a validade ou a eficácia do casamento. O descumprimento de qualquer dos deveres matrimoniais não gera a possibilidade de o cônjuge credor buscar seu adimplemento em juízo. Com o fim do instituto da separação, não é mais permitido sequer imputar ao infrator a culpa pelo fim do amor. A partir da EC 66/10, a dissolução do casamento só pode decorrer do divórcio, que não admite questionamentos sobre causas e motivos (CC 1.580, $\left.\S 1^{\circ}\right)^{\prime}$. DIAS, Maria Berenice. Manual de direito das famílias. 10. ed. São Paulo: Editora Revista dos Tribunais, 2015. p. 169.

Em sentido contrário, TAVARES DA SILVA, Regina Beatriz. Reparação civil na separação e no divórcio. São Paulo: Saraiva, 1999. p. 157.

36 "Os únicos deveres comuns tanto aos cônjuges quanto aos companheiros que não violam a privacidade e a vida privada deles nem interferem em tal comunhão de vida são o dever de mútua assistência e o dever de sustento, guarda e educação dos filhos. Estes são deveres exigíveis e refletem interesse público relevante" (LÔBO, Paulo Luiz Netto. As vicissitudes da igualdade e dos deveres conjugais no direito brasileiro. Revista Brasileira de Direito de Família, Porto Alegre, v. 6, n. 26, p. 11, out./nov. 2004).

Cf. também SILVA, Marcos Alves da. Da monogamia... p. 315-317, v. 1: "relativamente ao direito de sustento, guarda e educação dos filhos, não se pode dizer tratar-se de um dever conjugal, já que independe do casamento. O mesmo pode ser dito sobre o dever de respeito e consideração mútuos, pois este é devido a toda pessoa que estabeleça convivência de qualquer natureza. Para o autor, o único mandamento que pode ser classificado como dever conjugal é o dever de mútua assistência, tanto em sua dimensão moral, consistente em cuidado e atenção, quanto em sua dimensão material, que se refere à provisão de meios para suprir as necessidades da família".

37 FACHIN, Luiz Edson. Famílias: entre o público e o privado. In: PEREIRA, Rodrigo da Cunha (Org.). Família: entre o público e o privado. Porto Alegre: Magister/IBDFAM, 2012. p. 163; LÔBO, Paulo Luiz Netto. Direito civil: famílias. 4. ed. São Paulo: Saraiva, 2011. p. 143. 


\section{Revista IBERC}

v. 2, n. 2, p. 01-35, mai.-ago./2019

www.responsabilidadecivil.org

É possível inferir que no tempo presente não mais se insculpe, de modo necessário, o dever de fidelidade como elemento intrínseco da manutenção de uma conjugalidade, dado que, se assim o fosse, o casamento exsurgiria como um instrumento de coerção e repressão sexual. A fidelidade formal se verteu na lealdade substancial. [...] E, ademais, a lealdade a um projeto de vida não faz morada na fria previsão normativa, mas sim no desejo e vontade daqueles que protagonizam tal projeto, e que nele buscam construir as suas vidas. ${ }^{38}$

Por sua vez, o dever de vida em comum, no domicílio conjugal, denominado de dever de coabitação, não se coaduna com a liberdade dos cônjuges em determinarem a possibilidade e a conveniência de viverem em domicílios separados. A imposição, além de anacrônica, não é justificável dentro do ordenamento jurídico brasileiro ${ }^{39}$, estando pautada em padrões culturais e morais ultrapassados, ainda mais se confrontada com norma do próprio Código Civil, que admite a pluralidade de domicílios (art. 71) e, ainda, com os princípios constitucionais basilares das relações existenciais. A opção pela vida em domicílio comum cabe somente aos cônjuges, de forma que a não observância do dever de coabitação é desprovida de efeitos legais e, portanto, inexigível. ${ }^{40}$

Do dever de coabitação e de vida em comum, parte da doutrina afirma que decorre a obrigação de manutenção de relações sexuais entre os cônjuges. A despeito do entendimento de parcela doutrinária ${ }^{41}$, não se sustenta ${ }^{42} \circ$ denominado débito conjugal dentro de uma ordem constitucional que erige como seu princípio máximo a dignidade da pessoa humana e que delineia, em consequência, a relação sexual como

\footnotetext{
${ }^{38}$ FACHIN, Luiz Edson. Famílias... p. 163.

39 DIAS, Maria Berenice. Manual de direito das famílias. 10. ed. São Paulo: Editora Revista dos Tribunais, 2015. p. 174.

${ }^{40}$ LÔBO, Paulo Luiz Netto. Direito civil... p. 128-129.

41 TAVARES DA SILVA, Regina Beatriz. Reparação civil na separação e no divórcio. São Paulo: Saraiva, 1999. PINHEIRO, Jorge Alberto Caras Altas Duarte. O núcleo intangível da comunhão conjugal: os deveres conjugais sexuais. Revista Brasileira de Direito das Famílias e Sucessões, v. 10, n. 4, p. 104, jun./jul. 2008.

42 "O simples fato de haver arrefecido a paixão ou o desejo não produz qualquer efeito. Ninguém pode ser condenado pela falta do estímulo indispensável para que os contatos físicos sejam um verdadeiro coroamento das relações afetivas que enlaçam o par. Afinal, não é o exercício da sexualidade que mantém o casamento. São muito mais a afetividade e o amor. Desarrazoado e desmedido pretender que a ausência de contato físico de natureza sexual seja reconhecida como inadimplemento de dever conjugal. Tal postura pode, perigosamente, chancelar a violência doméstica, sob a justificativa de garantir o exercício do direito ao contato sexual. Não se pode olvidar a tendência, que prevaleceu por muito tempo, ele desqualificar o estupro conjugal, que repousava na obrigação do coito para os parceiros e era cometido essencialmente por homens, em face do reconhecimento do direito ao exercício da sexualidade" (DIAS, Maria Berenice. Manual... p. 174).
} 


\section{Revista IBERC}

v. 2, n. 2, p. 01-35, mai.-ago./2019

www.responsabilidadecivil.org

um ato íntimo, voluntário, consensual, livre e espontâneo. ${ }^{43} \mathrm{~A}$ sexualidade e tampouco a procriação são os propósitos únicos da união entre cônjuges ou conviventes. ${ }^{44}$

Com efeito, a família constitucionalizada deve ser instrumento para promover a dignidade da pessoa humana, a autonomia existencial, a intimidade e a solidariedade ${ }^{45}$, não podendo, portanto, ser fonte ou motivação de restrições a quaisquer desses aspectos. As relações conjugais e convivenciais são marcadas pela horizontalidade, representada por indivíduos plenamente capazes de reger seus destinos e de eleger suas escolhas autonomamente. ${ }^{46}$

Nesse sentido, destaca-se em doutrina como melhor solução no que tange à incidência da responsabilidade civil nas relações conjugais e convivenciais, o entendimento de que o mero descumprimento de algum dever jurídico familiar não enseja o dever de indenizar. Assim:

Dependendo a incidência das regras de responsabilidade civil no âmbito do direito das famílias da efetiva prática de um ilícito danoso, nos moldes dos arts. 186 e 187, CC. Especificamente quanto ao dano moral, a sua incidência na seara da conjugalidade ocorrerá como em qualquer outro quadrante do direito civil, sendo necessário caracterizar uma violação a um interesse existencial concretamente merecedor de tutela. ${ }^{47}$

\footnotetext{
${ }^{43}$ SILVA, Marcos Alves da. Da monogamia: a sua superação como princípio estruturante do direito de família. V. 1. Curitiba: Juruá, 2013. p. 316,

${ }^{44}$ Registram-se, inclusive, na atualidade, casais que assumem serem assexuados. Relationships F.A.Q., do portal on-line Assexual Visibility and Education Network (AVEN). Disponível em: http://www.asexuality.org/home/?q=relationship.html. Acesso em: 12 jan. 2016.

45 "Os princípios constitucionais balizadores da relação conjugal têm na tutela da dignidade da pessoa humana seu princípio estruturante, de modo que dele decorrem os demais princípios, gerais ou específicos, que apontam para a concretização da igualdade, do respeito recíproco e à intimidade, da solidariedade, da autonomia, da liberdade, dentre os vários que possam orientar as relações dos dois eixos". CARBONERA, Silvana Maria. Reserva de intimidade: uma possível tutela da dignidade no espaço relacional da conjugalidade. Rio de Janeiro: Renovar, 2008. p. 271.

${ }^{46}$ Como elucida Silvana Carbonera: "Com uma atuação não interventora, mas vigilante, o sistema jurídico permite implementar o respeito à dignidade da pessoa humana na dimensão familiar conjugal na medida em que reconhece aos sujeitos liberdade e autonomia, não intervindo em aspectos pessoais que impliquem em restrição injustificada, sem respaldo constitucional, e dispensável, posto que se trata de uma relação entre dois adultos, que em tese já podem dirigir suas vidas" (CARBONERA, Silvana Maria. Reserva... p. 271).

${ }^{47}$ FARIAS, Cristiano Chaves de; NETTO, Felipe Peixoto Braga; ROSENVALD, Nelson. Novo Tratado de Responsabilidade Civil. 3. ed.. Rio de Janeiro: Saraiva, 2018. p. 1089. Destacam os autores: "o Estado deve interferir minimamente na subjetividade dos indivíduos e na afetividade, sob pena de acabar impondo mais uma vingança do que uma reparação propriamente dita, já que o amor não é instrumento de lucro ou uso, sendo temerário se pensar um mercado de seguro afetivo no qual as pessoas converterão os riscos das perdas emocionais em um interesse segurável".
} 


\section{Revista IBERC}

v. 2, n. 2, p. 01-35, mai.-ago./2019

www.responsabilidadecivil.org

Partindo-se do entendimento de que o casamento e a união estável são instrumentos de desenvolvimento da personalidade em contraponto à realidade contemporânea, em que tudo é precificado, questiona-se se quantificar o inadimplemento afetivo é a melhor saída.

Sob essa perspectiva, adota-se neste trabalho para fins de definição do dano moral, a corrente capitaneada por Maria Celina Bodin de Moraes que o conceitua como "lesão a qualquer dos aspectos da dignidade humana, que se encontra fundada em quatro substratos que, reunidos, a corporificam: os princípios da igualdade, da integridade psicofísica, da liberdade e da solidariedade". ${ }^{48}$

Portanto, o dano injusto que se colocará como fato gerador da reparação não será o mero descumprimento dos deveres conjugais, como a fidelidade entre os cônjuges e a lealdade entre os companheiros, mas sim outros bens jurídicos atingidos, ou seja, qualquer aspecto que viole a dignidade. Tanto no contexto do casamento, como no contexto do divórcio e da dissolução da união estável.

Verifica-se que esse é também o posicionamento da jurisprudência majoritária mais recente, tanto do Superior Tribunal de Justiça como dos principais Tribunais estaduais brasileiros, que tem se firmado no sentido de que o término da sociedade conjugal não é suficiente para configurar o dever de reparar, assim como, a violação do dever de fidelidade não configura ato ilícito. Prevalece o entendimento de que a mera relação extraconjugal, por si só, não gera responsabilidade do cônjuge, bem como inexiste dever de fidelidade do terceiro envolvido. ${ }^{49}$

\footnotetext{
${ }^{48}$ BODIN DE MORAES, Maria Celina Bodin de. Danos... p. 327.

49 BRASIL. STJ. RESPONSABILIDADE CIVIL. DANO MORAL. ADULTÉRIO. AČ̃̃ AJUIZADA PELO MARIDO TRAÍDO EM FACE DO CÚMPLICE DA EX-ESPOSA. ATO ILÍCITO. INEXISTÊNCIA. AUSÊNCIA DE VIOLAÇÃO DE NORMA POSTA. 1. O cúmplice de cônjuge infiel não tem o dever de indenizar o traído, uma vez que o conceito de ilicitude está imbricado na violação de um dever legal ou contratual, do qual resulta dano para outrem, e não há no ordenamento jurídico pátrio norma de direito público ou privado que obrigue terceiros a velar pela fidelidade conjugal em casamento do qual não faz parte. 2. Não há como o Judiciário impor um "não fazer" ao cúmplice, decorrendo disso a impossibilidade de se indenizar o ato por inexistência de norma posta - legal e não moral - que assim determine. O réu é estranho à relação jurídica existente entre o autor e sua ex-esposa, relação da qual se origina o dever de fidelidade mencionado no art. 1.566, inciso I, do Código Civil de 2002. 3. De outra parte, não se reconhece solidariedade do réu por suposto ilícito praticado pela ex-esposa do autor, tendo em vista que o art. 942, caput e § único, do CC/02 (art. 1.518
} 


\section{Revista IBERC}

v. 2, n. 2, p. 01-35, mai.-ago./2019

www.responsabilidadecivil.org

As decisões são no sentido de que para haver a "responsabilidade de indenizar é imperioso a existência do dano, ilícito e nexo de causalidade. A infidelidade, por si só, não caracteriza o dano, sendo necessária a demonstração do momento ou fato que lhe causou o constrangimento público alegado" 50 , ou seja, "ostensividade ou publicidade justificadoras da reparação pretendida" ${ }^{51}$

do CC/16), somente tem aplicação quando o ato do co-autor ou partícipe for, em si, ilícito, o que não se verifica na hipótese dos autos. 4. Recurso especial não conhecido. Recurso Especial no 1122547. $4^{\mathrm{a}}$ Turma. Relator: Min. Luis Felipe Salomão. J. em 10/11/2009. DJ. 27.11.2009; BRASIL. TJRS. Tribunal de Justiça do Rio Grande do Sul. APELAÇÃO CÍVEL. RESPONSABILIDADE CIVIL. AÇÃO DE INDENIZAÇÃO POR DANOS MORAIS. MÉDICO QUE TERIA MANTIDO RELAÇÃO EXTRACONJUGAL COM A EX-ESPOSA DO AUTOR NA CONSTÂNCIA DO MATRIMÔNIO. AUSENTE ILICITUDE. IMPROCEDÊNCIA MANTIDA. AGRAVO RETIDO - Mostrando-se desnecessário, no entendimento do juiz de primeiro grau, destinatário da produção da prova, que fosse produzida prova oral, não há falar em ocorrência de cerceamento de defesa. Embora se pudesse cogitar de eventual acolhimento do agravo retido, baseado na premissa de que o autor não produziu prova acerca das alegações que constituem sua causa de pedir, porque não the fora oportunizado, tal providência seria inócua diante da interpretação jurídica empreendida à questão em exame, relativa ao fato de que o demandado, na condição cirurgião plástico que realizou procedimento na ex-esposa do autor, valeu-se de tal condição para manter relação extraconjugal. Na realidade, o que se quer dizer neste ponto, mormente quanto à utilidade de eventual provimento do agravo retido, é que provada ou não a efetiva ocorrência da relação extraconjugal aventada na petição inicial, tal circunstância não teria o condão de interferir quanto ao desfecho da demanda, considerando-se, pois, o entendimento preconizado pela própria sentença, no sentido da não configuração da ilicitude por parte do terceiro, em casos como o presente. - RESPONSABILIDADE CIVIL SUBJETIVA - O dever de reparar o dano advindo da prática de ato ilícito, tratando-se de ação baseada na responsabilidade civil subjetiva, regrada pelo art. 927 do Código Civil, exige o exame da questão com base nos pressupostos da matéria, quais sejam, a ação/omissão, a culpa, o nexo causal e o resultado danoso. Para que obtenha êxito na sua ação indenizatória, ao autor impõe-se juntar aos autos elementos que comprovem a presença de tais elementos caracterizadores da responsabilidade civil subjetiva. - SITUAÇÃO CONCRETA DOS AUTOS - Caso em que a eventual ocorrência de relação extraconjugal não tem o condão de responsabilizar o terceiro por supostos danos morais. A obrigação de observar os deveres do casamento previstos no art. 1.566, do Código Civil, é dirigida aos cônjuges reciprocamente. A dissolução da sociedade conjugal ocorre por força da fragilidade do afeto ou mesmo o natural desgaste da relação durante a convivência dos consortes, constituindo-se eventual traição ou mesmo relação extraconjugal não em fator motivador da ruptura da união, mas sim mera decorrência fática de um relacionamento que estava fadado ao insucesso por responsabilidade exclusiva dos próprios cônjuges. Ainda que cediço que o adultério constitua em grave violação aos deveres do matrimônio, ocasionando, na maioria das vezes, sofrimento, decepção e o evidente fracasso da relação conjugal, a impossibilidade de manutenção da convivência configura situação prévia à configuração de uma relação extraconjugal. A vida em comum e a falta de afeto que permitem que situações como a narrada na petição inicial ocorram no nosso cotidiano com alguma frequência, não se podendo, portanto, atribuir eventual fracasso da relação a terceiro, que simplesmente ocupou um espaço que já havia. Precedentes do TJRS. Sentença de improcedência mantida. Agravo retido e apelo desprovidos. Apelação Cível n ${ }^{\circ}$ 70051519833. $9^{\mathrm{a}}$ CC. Relator: Des. Leonel Pires Ohlweiler. Julg. 27.02.2013. DJ. 04.03.13.

50 BRASIL. TJRS. APELAÇÃO CÍVEL. INDENIZAÇÃO. DANO MORAL. EX-CÔNJUGE. DANO MATERIAL. ALIMENTOS. PATERNIDADE DESCONSTITUIDA EM AÇÃO NEGATÓRIA DE PATERNIDADE. DANO MORAL. Não há dano a ser reparado quanto aos dissabores decorrentes do término da sociedade conjugal. Para a configuração da responsabilidade de indenizar é imperioso a existência do dano, ilícito e nexo de causalidade. A infidelidade, por si só, não caracteriza o dano, sendo necessária a demonstração do momento ou fato que Ihe causou o constrangimento público alegado. Ademais, não há mais a perquirição da culpa na dissolução da sociedade conjugal, sob pena de violação a liberdade, a intimidade e a vida privada do casal. Também não cabe buscar a indenização frente ao cúmplice do excônjuge, visto que inviável exigir deste o cumprimento de deveres inerentes ao casamento. A procedência da

Revista IBERC, Minas Gerais, v. 2, n. 2, p. 01-35, mai.-ago./2019 


\section{Revista IBERC}

v. 2, n. 2, p. 01-35, mai.-ago./2019

www.responsabilidadecivil.org

Por outro lado, a violação de qualquer aspecto da dignidade enseja a reparação por dano moral. Nesse sentido, encontram-se julgados que reconhecem a violação à dignidade mediante a comprovação de ilícitos como injúria grave, ofensa à liberdade, agressões físicas decorrentes de violência doméstica, ${ }^{52}$ ocultação da paternidade biológica $^{53}$ e, principalmente, a violação ao direito de imagem, de intimidade e privacidade.

ação negatória de paternidade não gera direito a indenização, haja vista que não se amolda ipso facto as hipóteses de dano moral. DANO MATERIAL. Em primeiro lugar, destaca-se a ilegitimidade passiva dos apelados, porquanto a pensão alimentar foi concedida em prol do menor. Em segundo, salienta-se que a verba alimentar é irrepetível, não sendo cabível o ressarcimento pleiteado. Apelação desprovida. Apelação Cível $n^{\circ}$ 70031864119. $7^{\text {a }}$ CC. Relator: Des. Jorge Luís Dall'Agnol. Julg. 01.09.2010. DJ. 09.09.2010.

${ }^{51}$ BRASIL. STJ. Agravo em Recurso Especial $n^{\circ}$ 773.894. Relator: Min. João Otávio de Noronha. Julgamento: 05.08.16. DJ. 19.08.16.

52 BRASIL. TJRS. RESPONSABILIDADE CIVIL. AGRESSÃO FÍSICA. CÔNJUGES. SEPARAÇÃO. DESAVENÇAS. DANO MORAL OCORRENTE. ÔNUS DA PROVA. QUANTUM. 1. Caso em que restou evidenciada a agressão sofrida pela parte autora. Ausência de comprovação de fato extintivo, modificativo ou impeditivo à tese inicial. Contexto probatório que embasa a causa de pedir trazida pela parte demandante. Excesso na conduta do requerido. Agir desarrazoado. Dano moral ocorrente. Dever de indenizar configurado. 2. O montante indenizatório aos abalos extrapatrimoniais deve observar a proporcionalidade, razoabilidade e o caráter reparatório/punitivo. Valor minorado para $\mathrm{R} \$ 4.000,00$ (quatro mil reais). Mantidos os critérios de atualização da sentença, sob pena de incorrer em reformatio in pejus. DERAM PARCIAL PROVIMENTO À APELAÇÃO. UNÂNIME. Apelação Cível $n^{\circ}$ 70066071580. 10ª CC. Relator: Des. Jorge Alberto Schreiner Pestana. Julg. 17.12.15. DJ. 21.01.16.

${ }^{53}$ BRASIL. STJ. AGRAVO EM RECURSO ESPECIAL. UNIÃO ESTÁVEL. DANO MORAL. 1. OFENSA AO ART. 535 DO CPC. DECISÃO CONTRÁRIA AO INTERESSE DAS PARTES. INEXISTÊNCIA DE OMISSÃO. 2. UNIÃO ESTÁVEL. DEVER DE FIDELIDADE. DESCUMPRIMENTO. OMISSÃO SOBRE A VERDADEIRA PATERNIDADE BIOLÓGICA DE FILHO NASCIDO NA CONSTÂNCIA DO CASAMENTO. DANO MORAL CONFIGURADO. PRECEDENTES. 3. AGRAVO CONHECIDO PARA DAR PARCIAL PROVIMENTO AO RECURSO ESPECIAL. Agravo em Recurso Especial $n^{\circ}$ 641.396. Relator: Min. Marco Aurélio Bellizze. Julg. 16.06.15. DJ. 01.07.15; BRASIL. STJ. RECURSO ESPECIAL. DIREITO CIVIL E PROCESSUAL. DANOS MATERIAIS E MORAIS. ALIMENTOS. IRREPETIBILIDADE. DESCUMPRIMENTO DO DEVER DE FIDELIDADE. OMISSÃO SOBRE A VERDADEIRA PATERNIDADE BIOLÓGICA DE FILHO NASCIDO NA CONSTÂNCIA DO CASAMENTO. DOR MORAL CONFIGURADA. REDUÇÃO DO VALOR INDENIZATÓRIO. 1. Os alimentos pagos a menor para prover as condições de sua subsistência são irrepetíveis. 2 . $O$ elo de afetividade determinante para a assunção voluntária da paternidade presumidamente legítima pelo nascimento de criança na constância do casamento não invalida a relação construída com o pai socioafetivo ao longo do período de convivência. 3. 0 dever de fidelidade recíproca dos cônjuges é atributo básico do casamento e não se estende ao cúmplice de traição a quem não pode ser imputado o fracasso da sociedade conjugal por falta de previsão legal. 4 . 0 cônjuge que deliberadamente omite a verdadeira paternidade biológica do filho gerado na constância do casamento viola o dever de boa-fé, ferindo a dignidade do companheiro (honra subjetiva) induzido a erro acerca de relevantíssimo aspecto da vida que é o exercício da paternidade, verdadeiro projeto de vida. 5. A família é o centro de preservação da pessoa e base mestra da sociedade (art. 226 CF/88) devendo-se preservar no seu âmago a intimidade, a reputação e a autoestima dos seus membros. 6. Impõe-se a redução do valor fixado a título de danos morais por representar solução coerente com o sistema. 7. Recurso especial do autor desprovido; recurso especial da primeira corré parcialmente provido e do segundo corréu provido para julgar improcedente o pedido de sua condenação, arcando o autor, neste caso, com as despesas processuais e honorários advocatícios. Recurso Especial $n^{\circ}$ 922462. $3^{a}$ Turma. Relator: Min. Ricardo Villas Bôas Cueva. Julg. 04.04.13. DJ. 13.05.13.

Revista IBERC, Minas Gerais, v. 2, n. 2, p. 01-35, mai.-ago./2019 


\title{
Revista IBERC
}

v. 2, n. 2, p. 01-35, mai.-ago./2019

www.responsabilidadecivil.org

Em sentido contrário, recente decisão do Tribunal de Justiça de São Paulo ${ }^{54}$ decidiu que devido a infidelidade virtual comprovada nos autos, considerada em razão de troca de mensagens eletrônicas de cunho amoroso e sentimental, ainda que virtualmente, a esposa não teria direito à pensão alimentícia, sendo aplicada como fundamentação, a tese da indignidade com base no art. 1.708 do Código Civil.

Polêmica foi instaurada na doutrina após notícia jornalística afirmando que o Superior Tribunal de Justiça, ao julgar recurso proposto em face da referida decisão, havia reconhecido que "o infiel não tem direito a pensão alimentícia" ${ }^{55}$, quando, em verdade, se limitou o STJ no julgamento do caso em tela, em decisão monocrática a aplicar a Súmula 7 do referido Tribunal, a qual dispõe que "a pretensão de simples reexame de prova não enseja Recurso Especial" ${ }^{56}$

\begin{abstract}
${ }^{54}$ BRASIL. TJSP. INDIGNIDADE. CÔNJUGE. INFIDELIDADE VIRTUAL. COMPROVAÇÃO. CESSAÇÃO DA OBRIGAÇÃO ALIMENTAR. PROCEDÊNCIA DO PEDIDO. Litispendência. Pressuposto processual negativo. Correlação com ação de separação judicial. Impossibilidade. Ausência de identidade entre os elementos identificadores da ação. Efeitos diversos. Extinção afastada. Julgamento do mérito, nos termos do art. 515, § $3^{\circ}$, do CPC. Indignidade. Cônjuge. Reconhecimento. Infidelidade virtual comprovada nos autos. A ré manteve relacionamento afetivo com outro homem durante o casamento. Troca de mensagens eletrônicas de cunho amoroso e sentimental. Caracterização de infidelidade, ainda que virtual. Ofensa à dignidade do autor. A infidelidade ofende a dignidade do outro cônjuge porquanto o comportamento do infiel provoca a ruptura do elo firmado entre o casal ao tempo do início do compromisso, rompendo o vínculo de confiança e de segurança estabelecido pela relação afetiva. A infidelidade ofende diretamente a honra subjetiva do cônjuge e as consequências se perpetuam no tempo, porquanto os sentimentos negativos que povoam a mente do inocente não desaparecem com o término da relação conjugal. Tampouco se pode olvidar que a infidelidade conjugal causa ofensa à honra objetiva do inocente, que passa a ter sua vida social marcada pela mácula que lhe foi imposta pelo outro consorte. Mesmo que não se entenda que houve infidelidade, a grave conduta indevida da ré em relação ao seu cônjuge demonstrou inequívoca ofensa aos deveres do casamento e à indignidade marital do autor. Indignidade reconhecida. Cessação da obrigação alimentar declarada. Procedência do pedido. Recurso provido. Apelação cível nº 0036600-97.2012.8.26.0002. $3^{\text {a }}$ Vara de Família e Sucessões. Relator Des. Carlos Alberto Garbi. Julg. 15/03/2016.
\end{abstract}

55 Disponível em: https://politica.estadao.com.br/blogs/fausto-macedo/o-infiel-nao-tem-direito-a-pensaoalimenticia-reconhece-o-stj/. Acesso em 11 fev. 2019.

${ }^{56}$ BRASIL. STJ. INDIGNIDADE. CÔNJUGE. INFIDELIDADE VIRTUAL. COMPROVAÇÃO. CESSAÇÃO DA OBRIGAÇÃO ALIMENTAR. PROCEDÊNCIA DO PEDIDO. Litispendência. Pressuposto processual negativo. Correlação com ação de separação judicial. Impossibilidade. Ausência de identidade entre os elementos identificadores da ação. Efeitos diversos. Extinção afastada. Julgamento do mérito, nos termos do art. 515, $\S 3^{\circ}$, do CPC. Indignidade. Cônjuge. Reconhecimento. Infidelidade virtual comprovada nos autos. A ré manteve relacionamento afetivo com outro homem durante o casamento. Troca de mensagens eletrônicas de cunho amoroso e sentimental. Caracterização de infidelidade, ainda que virtual. Ofensa à dignidade do autor. A infidelidade ofende a dignidade do outro cônjuge porquanto o comportamento do infiel provoca a ruptura do elo firmado entre o casal ao tempo do início do compromisso, rompendo o vínculo de confiança e de segurança estabelecido pela relação afetiva. A infidelidade ofende diretamente a honra subjetiva do cônjuge e as consequências se perpetuam no tempo, porquanto os sentimentos negativos que povoam a mente do inocente não desaparecem com o término da relação conjugal. Tampouco se pode olvidar que a infidelidade conjugal causa ofensa à honra objetiva do inocente, que passa a ter sua vida social marcada pela mácula que Ihe foi imposta pelo outro consorte. Mesmo que não se entenda que houve infidelidade, a

Revista IBERC, Minas Gerais, v. 2, n. 2, p. 01-35, mai.-ago./2019 


\section{Revista IBERC}

v. 2, n. 2, p. 01-35, mai.-ago./2019

www.responsabilidadecivil.org

Em outra notícia esclarecedora sobre o caso veiculada no mesmo jornal de grande circulação, lamentou-se "que a questão não tenha sido apreciada, haja vista a relevância do tema e a oportunidade de difusão sobre a correta interpretação jurídica da legislação federal de regência". ${ }^{57}$

Como bem destacado na segunda notícia jornalística, "o parágrafo único do artigo 1.708 do Código Civil - preceito legal utilizado para extirpar da consorte seu direito à pensão alimentícia - não trouxe o conceito legal de indignidade para fins alimentícios, tratando-se de cláusula geral que, por ser limitadora de direitos, deve ser interpretada restritivamente."

Nesse prisma, vale lembrar que ainda que o acórdão do TJSP não tenha levado em consideração a Emenda Constitucional 66 de 2010, que extinguiu a discussão da culpa nas dissoluções conjugais, caberia no caso em tela tão somente limitar-se o valor dos alimentos ao indispensável para sobrevivência do cônjuge culpado, nos moldes dos arts. 1.702 e 1.704 do $C C / 2002^{59}$, embora também em uma interpretação não sistemática e em total dissonância com o Direito de Família constitucionalizado.

Diferentemente da questão limitada à culpa pelo término da relação conjugal decorrente de infidelidade virtual, ${ }^{60}$ a violação à dignidade da pessoa humana no ambiente virtual, principalmente nas hipóteses de lesão ao direito de imagem, intimidade e privacidade, se sujeita ao instituto da responsabilidade civil, sendo necessária sua aplicação e adaptação às novas e cada vez mais frequentes situações cotidianas.

grave conduta indevida da ré em relação ao seu cônjuge demonstrou inequívoca ofensa aos deveres do casamento e à indignidade marital do autor. Indignidade reconhecida. Cessação da obrigação alimentar declarada. Procedência do pedido. Recurso provido. Agravo em Recurso Especial $n^{\circ} 1.269 .166$ - SP. Relatora Min. Maria Isabel Gallotti. J. em 18/12/2018. DJ. 01/02/2019.

57 Disponível em: https://politica.estadao.com.br/blogs/fausto-macedo/o-infiel-nao-tem-direito-a-pensaoalimenticia/. Acesso em: 11 fev. 2019.

58 Disponível em: https://politica.estadao.com.br/blogs/fausto-macedo/o-infiel-nao-tem-direito-a-pensaoalimenticia/. Acesso em: 11 fev. 2019.

59 Art. 1.702, do Código Civil de 2002. Na separação judicial litigiosa, sendo um dos cônjuges inocente e desprovido de recursos, prestar-Ihe-á o outro a pensão alimentícia que o juiz fixar, obedecidos os critérios estabelecidos no art. 1.694.

Art. 1.704, do Código Civil de 2002. Se um dos cônjuges separados judicialmente vier a necessitar de alimentos, será o outro obrigado a prestá-los mediante pensão a ser fixada pelo juiz, caso não tenha sido declarado culpado na ação de separação judicial.

60 Sobre o tema TITO, Karenina. "Infidelidade virtual" - Responsabilidade civil no mundo digital?". In: CALHEIROS, Clara; et al. (Coord.), Direito na Lusofonia. Direito e novas tecnologias. Universidade do Minho. Março de 2018. pp. 239-246.

Revista IBERC, Minas Gerais, v. 2, n. 2, p. 01-35, mai.-ago./2019 


\title{
Revista IBERC
}

v. 2, n. 2, p. 01-35, mai.-ago./2019

www.responsabilidadecivil.org

Como adverte Stefano $\operatorname{Rodotá}^{61}$, a atual mercantilização de dados associada a "perfis sociais" oferece novos riscos à privacidade dos indivíduos, modificando a relação entre fornecedores e consumidores e reduzindo a autonomia destes.

Assim também destacam Chiara de Teffé e Maria Celina Bodin de Moraes que:

\begin{abstract}
O oferecimento de dados pessoais vem se tornando rotina no ambiente virtual, de forma que, muitas vezes, o indivíduo perde o controle sobre as próprias informações logo após fornecê-las, pouco sabendo sobre sua utilização e se serão repassadas, por meio de trocas comerciais, a terceiros. Uma vez munidas de tais informações, entidades privadas e governamentais tornam-se capazes de "rotular" e relacionar cada pessoa a um determinado padrão de hábitos e de comportamentos, situação que pode favorecer inclusive graves discriminações, principalmente se analisados dados sensíveis. ${ }^{62}$
\end{abstract}

Portanto, com a ampla utilização da Internet pela sociedade, não são poucas as decisões que conferem o dano moral por violação a direitos da personalidade tais como a imagem, a privacidade, a honra e a intimidade em razão da exposição da infidelidade nas relações familiares nas redes sociais. Nesses casos, o principal fundamento é a situação vexatória em que é colocada a pessoa diante da família, amigos e toda a comunidade.

Esse foi o entendimento do Tribunal de Justiça do Rio Grande do Sul, no caso em que foi amplamente divulgado na Internet vídeos que sugeriam a traição conjugal. ${ }^{63}$ No mesmo sentido, entendeu o Tribunal de Justiça do Rio de Janeiro que a exposição do

${ }^{61}$ RODOTÀ, Stefano. A vida... p. 62

62 TEFFÉ, Chiara Spadaccini de; BODIN DE MORAES, Maria Celina. Redes sociais... passim.

${ }^{63}$ BRASIL. TJRS. APELAÇÃO CÍVEL. RESPONSABILIDADE CIVIL. DIVULGAÇÃO DE IMAGENS ÍNTIMAS EM CANAL DE VÍDEOS E REDES SOCIAIS SEM AUTORIZAÇÃO. VÍDEOS QUE SUGEREM TRAIÇÃO CONJUGAL. DANOS MORAIS DIRETOS E EM RICOCHETE. - A divulgação na rede mundial de computadores de vídeos íntimos, ainda que não explícitos, mas sugestivos da ocorrência de sexo extraconjugal acarreta danos extrapatrimoniais à vítima direta (pessoa filmada) e também ao seu cônjuge, o chamado dano em ricochete. - A concordância tácita durante a gravação não é suficiente para afastar o dever de indenizar, porquanto a divulgação das imagens sem a autorização da pessoa filmada acarreta violação ao direito de intimidade e privacidade. - Quantum indenizatório que deve atentar para as circunstâncias do caso concreto, em que não foi demonstrada a extensão dos danos e não houve rompimento da relação matrimonial. Apelação dos autores parcialmente provida. Apelação do réu desprovida. Apelação Cível nº 70067051110. $9^{a}$ CC. Relator: Des. Carlos Eduardo Richinitti. DJ. 04.02.16. 


\section{Revista IBERC}

v. 2, n. 2, p. 01-35, mai.-ago./2019

www.responsabilidadecivil.org

adultério pela amante para terceiros via link de fotos em redes sociais gera o dever de indenizar. ${ }^{64}$

Em relação à responsabilidade do provedor de conteúdo, hoje chamado de aplicações, inicialmente, diante do aumento considerável no número de processos envolvendo danos a direitos da personalidade nas redes sociais, o Superior Tribunal de Justiça havia consolidado o entendimento de que o provedor responsável pela rede social responderia de forma subjetiva se, após sua ciência por notificação extrajudicial não tornasse indisponível o conteúdo apontado como danoso. ${ }^{65}$

No entanto, em 2014, com a entrada em vigor da Lei Federal $\mathrm{n}^{\circ}$ 12.965/14, conhecida como Marco Civil da Internet $(\mathrm{MCl})$, estabelecendo princípios, garantias e deveres para o uso da Internet no Brasil, determinou seu artigo 19, que o provedor de

${ }^{64}$ APELAÇÃO CÍVEL E RECURSO ADESIVO. AÇÃO INDENIZATÓRIA POR DANOS MORAIS. ENVIO DE MENSAGENS E FOTOS PELA RÉ À AUTORA E A TERCEIROS REFERENTES A CASO EXTRACONJUGAL QUE HAVIA MANTIDO COM SEU MARIDO. SENTENCA DE PROCEDÊNCIA PARCIAL. CONDENAÇÃO DA RÉ AO PAGAMENTO DE R $\$ 15.000,00$ A TíTULO DE DANOS MORAIS. 1. O teor jocoso e provocativo das mensagens enviadas não demonstra que a intenção da ré fosse a de simplesmente alertar a autora do caso que havia mantido com o seu marido, mas, ao revés, evidencia o propósito de humilhar, intimidar e ofender a autora, que, após descobrir a relação extraconjugal havida, aceitou manter o vínculo matrimonial. 2. Ademais, consta dos autos prova de que a ré buscava desmoralizar a autora em seu meio social ao enviar o link de álbum de fotos do casal para terceiros. 3. Princípio da dignidade da pessoa humana que deve ser preservado quando violada a intimidade, a vida privada, a honra e a imagem, assegurando aos ofendidos, na forma do art. $5^{\circ}$ da $\mathrm{CF}$, o ressarcimento moral. 4. Danos morais evidenciados, cujo valor fixado de $\mathrm{R} \$ 15.000,00$ não merece redução tampouco majoração, observadas as peculiaridades do caso concreto. Recursos conhecidos e desprovidos. (TJRJ. Apelação Cível no 0372328 -32.2009.8.19.0001 da $11^{\text {a }}$ Câmara Cível do TJRJ. Rel. Des(a). Fernando Cerqueira Chagas. J. em 07/06/2017).

65 BRASIL. STJ. RECURSO ESPECIAL. DIREITO DO CONSUMIDOR. PROVEDOR. MENSAGEM DE CONTEÚDO OFENSIVO. RETIRADA, REGISTRO DE NÚMERO DO IP. DANO MORAL. AUSÊNCIA. PROVIMENTO. 1- No caso de mensagens moralmente ofensivas, inseridas no site de provedor de conteúdo por usuário, não incide a regra de responsabilidade objetiva, prevista no art. 927, parágrafo único, do Cód. Civil/2002, pois não se configura risco inerente à atividade do provedor. Precedentes. 2- É o provedor de conteúdo obrigado a retirar imediatamente o conteúdo ofensivo, pena de responsabilidade solidária com o autor direto do dano. 3- O provedor de conteúdo é obrigado a viabilizar a identificação de usuários, coibindo o anonimato; o registro do número de protocolo (IP) dos computadores utilizados para cadastramento de contas na internet constitui meio de rastreamento de usuários, que ao provedor compete, necessariamente, providenciar. 4- Recurso Especial provido. Ação de indenização por danos morais julgada improcedente. Recurso Especial no 1.306.066/MT. $3^{a}$ Turma. Relator: Min. Sidnei Beneti. Julg. 17.04.2012. DJ. 02.05.2012.

BRASIL. STJ. DIREITO CIVIL E DO CONSUMIDOR. INTERNET. RELACÃO DE CONSUMO. INCIDÊNCIA DO CDC. GRATUIDADE DO SERVIÇO. INDIFERENÇA. PROVEDOR DE CONTEÚDO. FISCALIZAÇÃO PRÉVIA DO TEOR DAS INFORMAÇṌES POSTADAS NO SITE PELOS USUÁRIOS. DESNECESSIDADE. MENSAGENS DE CONTEÚDO OFENSIVO. DANO MORAL. RISCO INERENTE AO NEGÓCIO. INEXISTÊNCIA. CIÊNCIA DA EXISTÊNCIA DE CONTEÚDO ILÍCITO. RETIRADA IMEDIATA DO AR. DEVER. DISPONIBILIZAÇÃO DE MEIOS PARA IDENTIFICAÇÃO DE CADA USUÁRIO. DEVER. REGISTRO DO NÚMERO DE IP. SUFICIÊNCIA. Recurso Especial n ${ }^{\circ}$ 1.193.764/SP. $3^{\mathrm{a}}$ Turma. Relator: Min. Nancy Andrighi. Julg. 14.12.2010. DJ. 08.08.2011.

Revista IBERC, Minas Gerais, v. 2, n. 2, p. 01-35, mai.-ago./2019 
Revista IBERC

v. 2, n. 2, p. 01-35, mai.-ago./2019

www.responsabilidadecivil.org

aplicações será responsabilizado civilmente pelos danos decorrentes de conteúdo gerado por terceiros quando não removê-lo após notificação judicial e não mais extrajudicial ${ }^{66}$.

Já em casos que violem a privacidade de uma pessoa por publicação de conteúdo (imagens, vídeos ou outros materiais) contendo cenas de nudez ou de atos sexuais de caráter privado, a lei determina que o provedor terá o dever de retirar o material em seguida ao recebimento da notificação extrajudicial enviada pela vítima. ${ }^{67}$

Ressalta-se em doutrina ${ }^{68}$ que a divulgação desse tipo de conteúdo pode ocorrer tanto por ex-cônjuges ou ex-companheiros inconformados com o término da relação, como por terceiros (como hackers oportunistas que visam obter algum tipo de vantagem econômica). Por isso, nesses casos, justifica-se ter o legislador aberto mão das ordens judiciais para tornar o mais célere possível a retirada do conteúdo.

Com efeito, a disposição do art. 21 do $\mathrm{MCl}$ assume especial relevância tendo em vista o elevado número de vítimas da chamada pornografia de vingança (revenge porn), praticada principalmente em face das mulheres e nos grupos de adolescentes, via redes sociais e grupos de WhatsApp, como veremos mais à frente.

\section{A DIVULGAÇÃo DE IMAGENS E CONTEÚDOS ÍNTIMOS DE TERCEIROS E A PRÁTICA DO CYBERBULLYING NAS REDES SOCIAIS POR CRIANÇAS E ADOLESCENTES}

\footnotetext{
${ }^{66}$ Vale ressaltar que a constitucionalidade do artigo 19 está sendo questionada perante o Supremo Tribunal Federal, por meio do Recurso Extraordinário 1037396 ainda em julgamento. Art. 19 do MCl: "Com o intuito de assegurar a liberdade de expressão e impedir a censura, o provedor de aplicações de internet somente poderá ser responsabilizado civilmente por danos decorrentes de conteúdo gerado por terceiros se, após ordem judicial específica, não tomar as providências para, no âmbito e nos limites técnicos do seu serviço e dentro do prazo assinalado, tornar indisponível o conteúdo apontado como infringente, ressalvadas as disposições legais em contrário."

67 Art. 21 do $\mathrm{MCl}$ : Art. 21. O provedor de aplicações de internet que disponibilize conteúdo gerado por terceiros será responsabilizado subsidiariamente pela violação da intimidade decorrente da divulgação, sem autorização de seus participantes, de imagens, de vídeos ou de outros materiais contendo cenas de nudez ou de atos sexuais de caráter privado quando, após o recebimento de notificação pelo participante ou seu representante legal, deixar de promover, de forma diligente, no âmbito e nos limites técnicos do seu serviço, a indisponibilização desse conteúdo. Parágrafo único. A notificação prevista no caput deverá conter, sob pena de nulidade, elementos que permitam a identificação específica do material apontado como violador da intimidade do participante e a verificação da legitimidade para apresentação do pedido.

68 TEFFÉ, Chiara Spadaccini de; BODIN DE MORAES, Maria Celina. Redes sociais... passim.
} 
Outra grave questão envolvendo danos nas redes sociais é o combate ao cyberbullying, ${ }^{69}$ definido pela Lei 13.185/2015 como a "intimidação sistemática na rede mundial de computadores (cyberbullying), quando se usarem os instrumentos que lhe são próprios para depreciar, incitar a violência, adulterar fotos e dados pessoais com o intuito de criar meios de constrangimento psicossocial", vem sendo considerados questão de política pública no Brasil e em diversos países ao redor do mundo.

A questão é tão séria que vem ocasionando suicídios, principalmente entre crianças e adolescentes, denominado de bullycídio, ${ }^{70}$ sendo também identificado como possível causa de chacinas em escolas praticadas por adolescentes vítimas de bullying ${ }^{71}$ ou de cyberbullying em todo o mundo. ${ }^{72}$

Como destaque para o agravamento exponencial do dano e da violência psicossocial sofrida pela vítima, ressalta-se em doutrina as características específicas do cyberbullying, que "permite ataques anônimos; torna o dano indelével e, portanto, permanente; desconhece limites espaciais; e pode envolver um número significativamente maior de expectadores" ${ }^{73}$

Forma de violência também considerada como uma das principais causas de bullying e cyberbullying entre adolescentes nas escolas é a pornografia da vingança ou

\footnotetext{
69 Art. $2^{\circ}$ Parágrafo único, da Lei $13.185 / 2015$. O bullying também é definido na mesma lei, no seu art. $1^{\circ} \S 1^{\circ}$, da Lei 13.185/2015: "No contexto e para os fins desta Lei, considera-se intimidação sistemática (bullying) todo ato de violência física ou psicológica, intencional e repetitivo que ocorre sem motivação evidente, praticado por indivíduo ou grupo, contra uma ou mais pessoas, com o objetivo de intimidá-la ou agredi-la, causando dor e angústia à vítima, em uma relação de desequilíbrio de poder entre as partes envolvidas".

${ }_{70}$ Dez casos de bullying que tiveram consequências graves. Disponível em: http://www.iefap.com.br/noticia/10-casos-de-bullying-que-tiveram-consequencias-graves. Acesso em: 9 out. 2018.

${ }^{71}$ No Brasil, o "Massacre de Realengo" ocorrido em 2011, chamou a atenção do mundo quando, no Rio de Janeiro, Wellington Menezes de Oliveira, entrou armado em uma escola e tirou a vida de 12 adolescentes antes de cometer suicídio. O autor do massacre havia sido aluno da mesma escola e teria sofrido com bullying, motivo pelo qual especula-se que o fez planejar o massacre. As famílias de todas as vítimas desenvolveram a "Associação dos Anjos de Realengo" com o intuito de lutar contra o bullying e evitar a formação de outros jovens que, assim como Wellington, acabam recorrendo a atitudes violentas diante da intimidação.

72 Bullying motivou 87 ataques em escolas, diz estudo dos EUA. Portal G1, 16 abr. 2011. Disponível em: http://g1.globo.com/educacao/noticia/2011/04/bullying-motivou-87-de-ataques-em-escolas-diz-estudo-doseua.html. Acesso em 12. out. 2018.

${ }^{73}$ SCHREIBER, Anderson. Cyberbullying: responsabilidade civil e efeitos na família. Disponível em:
}

http://www.cartaforense.com.br/m/conteudo/colunas/cyberbullying-responsabilidade-civil-e-efeitos-nafamilia/18295. Acesso em 12. out. 2018. 


\section{Revista IBERC}

v. 2, n. 2, p. 01-35, mai.-ago./2019

www.responsabilidadecivil.org

revenge porn ${ }^{74}$. Ela consiste na prática de um ato ilícito que se materializa com a divulgação em sites, aplicativos e redes sociais de imagens com cenas de intimidade, nudez e sexo, sem o consentimento das pessoas envolvidas, com o único objetivo de colocá-las em situação vexatória e constrangedora diante dos amigos, pais, parentes, escola e toda a sociedade. ${ }^{75}$ Nesse caso, em regra, o intuito do ofensor é vingar-se de alguém que feriu seus sentimentos ou terminou um relacionamento. ${ }^{76}$

Caso emblemático sobre o assunto ocorreu em 2014, pelo uso do aplicativo Secret e gerou grande discussão no país $^{77}$ pela prática frequente de bullying e disseminação de imagens de jovens nuas ${ }^{78}$ de modo aparentemente anônimo. Devido aos abusos no uso do aplicativo para divulgação de imagens e textos de terceiros, em agosto de 2014, foi deferida medida liminar requerida pelo Ministério Público do Espírito Santo na Ação Civil Pública n. 0028553-98.2014.8.08.0024 para determinar que o Google e a Apple retirassem de suas lojas virtuais o referido aplicativo. ${ }^{79}$

A enxurrada de casos de bullying e cyberbullying no Brasil gerou a promulgação de duas leis e já chegou ao Superior Tribunal de Justiça ${ }^{80}$, demonstrando não só a gravidade da questão como a necessidade de uma reflexão mais aprofundada e multidisciplinar sobre o tema. ${ }^{81}$

No âmbito da responsabilidade civil, o sistema vigente dispõe que os pais são responsáveis pela reparação civil em relação aos filhos menores que estiverem sob sua

74 FRANKS, Mary Ann. Criminalizing Revenge Porn: Frequently Asked Questions. Disponível em: https://ssrn.com/abstract=2337998. Acesso em: 18 fev. 2017.

75 TEFFÉ, Chiara Spadaccini de. Divulgação não autorizada de imagens íntimas na Internet: o caso da pornografia de vingança. In: BODIN DE MORAES, Maria Celina; MULHOLLAND, Caitlin (Org.). Privacidade hoje: Anais do I Seminário de Direito Civil da PUC-Rio. Publicado em 11 de julho de 2018. Disponível em: https://www.academia.edu/35797545/Divulgação_não_autorizada_de_imagens_íntimas_na_Internet_o_caso _da_pornografia_de_vingança. Acesso em 12 ago. 2018.

76 Disponível em: http://www.revistaforum.com.br/blog/2013/11/revenge-porn-divulgacao-de-fotosintimasculmina-com-suicidio-de-duas-jovens/. Acesso em: 18 abr.2016.

77 TEFFÉ, Chiara Spadaccini de; BODIN DE MORAES, Maria Celina. Redes sociais... passim.

${ }^{78}$ Disponível em https://link.estadao.com.br/noticias/geral,brasileiros-vao-entrar-com-processo-para-tirar-appsecret-do-ar,10000030757. Acesso em 25.02.19.

79 TEFFÉ, Chiara Spadaccini de. Divulgação... passim.

80 BRASIL. Superior Tribunal de Justiça. Recurso Especial $n^{\circ}$ 1.517.973. $4^{\mathrm{a}}$ Turma. Relator: Min. Luis Felipe Salomão. J. em 16.11.17. DJ. 01.02.2018. BRASIL. Superior Tribunal de Justiça. Recurso Especial $n^{\circ}$ 1.639.690. Relator: Min. Regina Helena Costa. Julg. 30.11.16. DJ. 09.12.16 e BRASIL. Superior Tribunal de Justiça. Agravo em Recurso Especial n 124.562. Relator: Min. Antonio Carlos Ferreira. Julg. 02.02.15.

${ }^{81}$ Lei $n^{\circ} 13.185 / 2015$ e Lei $n^{\circ} 13.663 / 2018$.

Revista IBERC, Minas Gerais, v. 2, n. 2, p. 01-35, mai.-ago./2019 


\section{Revista IBERC}

v. 2, n. 2, p. 01-35, mai.-ago./2019

www.responsabilidadecivil.org

autoridade e em sua companhia. ${ }^{82}$ Adverte-se em doutrina que "embora essa posição seja tranquila em nossa jurisprudência, na prática, já se chegou a afirmar que essa espécie de ação faz com que o cyberbullying arruíne a vida não de uma criança, mas sim de duas". ${ }^{83}$ Além da responsabilização dos pais, a lei brasileira prevê a responsabilidade civil dos estabelecimentos de ensino públicos e particulares se houver nexo de causalidade entre a ofensa e os deveres de cuidado que são impostos a tais entidades ${ }^{84}$.

No entanto, tratando-se de cyberbullying difícil se faz configurar a responsabilidade por atos além das fronteiras físicas do ambiente escolar, já que não há qualquer ingerência do estabelecimento de ensino em relação à criação de grupos de WhatsApp ${ }^{85}$, tampouco ao comportamento dos alunos nas redes sociais.

No Brasil, a recente lei editada em 2018 objetivou combater o bullying e o cyberbullying no ambiente escolar, dispondo que "os estabelecimentos de ensino terão a incumbência de promover medidas de conscientização, de prevenção e de combate a todos os tipos de violência, especialmente a intimidação sistemática (bullying), no âmbito das escolas; bem como estabelecer ações destinadas a promover a cultura de paz nas escolas”. ${ }^{86} \mathrm{Na}$ França, foi aprovada em caráter definitivo pelo Parlamento, lei que proíbe a utilização de telefones celulares e qualquer objeto conectado à internet, como tablets e relógios, em escolas públicas, para crianças entre 6 e 15 anos de idade. ${ }^{87}$

É preciso refletir se as responsabilidades civil e penal têm se mostrado eficiente no combate à prática e à prevenção do bullying e do cyberbullying. Também é discutível se medidas, como a proibição de uso de celulares nas escolas na França são, de fato, as mais adequadas, pois a opção por um paternalismo exacerbado ao invés de uma real auto implicação dos adolescentes, pais, escolas e sociedade não parece a melhor solução.

\footnotetext{
${ }^{82}$ Art. 932 do CC/2002.

${ }^{83}$ SCHREIBER, Anderson. Cyberbullying... passim.

${ }^{84}$ GODINHO, Adriano Marteleto; DRUMOND, Marcela Maia de Andrade. Autoridade Parental e cyberbullying. In: TEIXEIRA, Ana Carolina Brochado; DADALTO, Luciana (orgs). Autoridade Parental: dilemas e desafios contemporâneos. Indiatuba, SP. Editora: Foco, 2019, fl. 183.

${ }^{85}$ Uma das modalidades do cyberbullying é denominada de cyberostracismo, que se configura na exclusão de grupos de WhatsApp.

${ }^{86}$ Art. 12 da Lei $n^{\circ} 13.663 / 2018$.

87 Disponível em: https://g1.globo.com/educacao/noticia/2018/07/31/parlamento-frances-aprova-proibicaodos-celulares-em-escolas-na-franca.ghtml. Acesso em 12. out. 2018.
} 


\section{Revista IBERC}

v. 2, n. 2, p. 01-35, mai.-ago./2019

www.responsabilidadecivil.org

Em verdade, a objetivação da responsabilidade civil e a imposição da tutela das vítimas de danos imateriais - e não apenas puramente econômicos - alinham o direito civil com os princípios constitucionais que contribuíram para humanizar o instituto. A responsabilidade civil, assim, passa a cumprir uma função social, repartindo os riscos e não permitindo que as vítimas arquem com as consequências dos danos que sofreram. ${ }^{88}$

Para além disso, em estudo doutrinário aprofundado sobre o tema destacou-se as práticas restaurativas e as propostas de difusão de uma cultura de paz como estratégias para a pacificação dos $\operatorname{conflitos}^{89}$ e para a ressignificação das ações nas práticas docentes.

A necessidade de uma abordagem multidisciplinar tem se mostrado indispensável para a realização de um verdadeiro combate à prática do bullying e do cyberbullying. Nesse cenário é que os métodos não adversariais de solução de conflitos aparecem como uma opção mais eficiente na medida em que, possibilitam um real envolvimento da família, da escola e de toda a sociedade civil tornando viável uma efetiva e sustentável solução do problema.

\section{5. À GUISA DE CONCLUSÃO: OS MÉTODOS ADEQUADOS PARA RESOLUÇÃO DE CONFLITOS E A BUSCA DA CONSTRUÇÃO DA PAZ}

O filósofo Schopenhauer comparou o dilema humano ao de dois porcos espinhos que tentam sobreviver a um inverno gelado. Para não morrerem congelados, eles procuram calor e conforto aproximando-se. Mas, quanto mais perto chegam, mais se furam com seus espinhos. Machucados e irritados vão para bem longe um do outro, para

\footnotetext{
${ }^{88}$ GODINHO, Adriano Marteleto; DRUMOND, Marcela Maia de Andrade. Autoridade Parental... p. 182.

${ }^{89}$ A justiça restaurativa é uma ideia que vem sendo trazida por diversos estudiosos para lidar com a questão do bullying escolar. Os círculos restaurativos buscam solucionar problemas entre alunos a partir do diálogo honesto entre eles. A ideia, como forma de prevenção parece interessante é vista com entusiasmo por pedagogos. [...] Outra medida relevante é a promoção de uma cultura generalizada de direitos humanos, que representa forte evolução social para qualquer sociedade. Nessa questão, escola e pais devem esmerar-se em criar seus filhos para que aprendam a ser solidários e responsáveis frente às outras pessoas. (COHEN, Fernanda. Agressões à pessoa em desenvolvimento: o problema do bullying escolar, Rio de Janeiro: UERJ, [Dissertação de Mestrado]. 2017).
} 


\section{Revista IBERC}

v. 2, n. 2, p. 01-35, mai.-ago./2019

www.responsabilidadecivil.org

evitar espetarem-se. Mas os pobres coitados perdem todo o conforto e o calor que poderiam se dar e voltam a ficar ameaçados de morrer de frio novamente. Então, mais uma vez se aproximam. Por fim, movimentando-se para frente e para trás, aprendem a viver um com o outro, de maneira que nenhum deles seja espetado seriamente, mas ainda assim permaneçam suficientemente juntos para viver com razoável conforto. Talvez seja esse o maior desafio da humanidade.

A mesma reflexão cabe aqui. Um dos maiores desafios da responsabilidade civil na atualidade refere-se a sua aplicação às relações familiares. Quando aplicada a relações continuadas, no que tange à prevenção de danos e à restauração das relações, como nas relações familiares e nas relações entre crianças e adolescentes no ambiente escolar, ela vem se mostrando bastante limitada. A judicialização da questão vem gerando, muitas vezes, o efeito reverso, pois embora a lide ponha fim ao processo, nessas relações raramente ela põe fim ao conflito. É preciso tratar do conflito doloroso, é preciso restaurar a relação, é preciso minimizar a dor.

Em doutrina, já se fala em um "direito de família mínimo", que propugna a menor intervenção possível do Estado nas relações familiares, ressalvadas as hipóteses excepcionais. ${ }^{90}$ Com efeito, e nesse caso, um dos aspectos que reforçam a base da principiologia minimalista do direito de família é a excessiva judicialização dos conflitos existentes nessa seara. ${ }^{91}$

A promoção dos métodos não adversariais de resolução de conflitos, como a mediação, os círculos restaurativos e a própria advocacia colaborativa, têm se mostrado muito mais eficientes para o resgate da relação e a real auto implicação e responsabilização das partes envolvidas, visto que, em tais métodos, há o "empoderamento" das partes sobre o conflito: de meros expectadores do litígio conduzido

\footnotetext{
90 ALVES, Leonardo Barreto Moreira. Direito de família mínimo: a possibilidade de aplicação e o campo de incidência da autonomia privada no direito de família. Rio de Janeiro: Lumen Juris, 2010. p.144.

91 VILELA MULTEDO, Renata. Liberdade e Família: limites para intervenção do Estado nas relações conjugais e parentais. Rio de Janeiro: Editora Processo, 2017. pp. 207 e 208.
} 


\section{Revista IBERC}

v. 2, n. 2, p. 01-35, mai.-ago./2019

www.responsabilidadecivil.org

pelos advogados e pelo magistrado, as partes passam a atores importantes, protagonistas e autores de sua própria solução. ${ }^{92}$

Hoje se questiona até que ponto delegar ao Estado a incumbência de dirimir as divergências familiares em relações continuadas é uma alternativa possível ou a melhor solução. Não por acaso é que os métodos adequados para a solução de conflitos vêm ganhando relevo no cenário nacional.

Desde 2010, quando editada a Resolução 125 do CNJ de 2010, o Brasil adotou uma política judiciária nacional de tratamento adequado dos conflitos, pelo qual criou-se um novo sistema de Justiça multiportas, tal como ocorrido nos Estados Unidos a partir da década de 1970. Em 2015, tanto a Lei de Mediação ${ }^{93}$ quanto o novo Código de Processo Civil $^{94}$ concretizaram essa preocupação com a mudança cultural, "promovendo a cultura da paz em substituição à cultura do litígio, da guerra". ${ }^{95}$

As limitações de uma decisão por meio do processo judicial são evidentes ao se considerar que, por mais preparados e cuidadosos que tenham sido os agentes judiciais envolvidos, a decisão é sempre tomada por um terceiro estranho às partes, que por elas decide, muitas vezes, com pouco conhecimento sobre as particularidades daquele contexto familiar. ${ }^{96}$ Assim, se perdem as peculiaridades do caso concreto, um dos principais atrativos do direito civil, constitucional.

Comparando-se o direito material ao desenrolar dos processos judiciais, o que se verifica é justamente a insuficiência destes e a demora na resolução dos litígios. Falase, ao término de um processo, em vencedores e perdedores; mas, no fundo, só há

\footnotetext{
${ }^{92}$ CABRAL, Antonio do Passo. CUNHA, Leonardo Carneiro da. Negociação direta ou resolução colaborativa de disputas (collaborative law): Mediação sem mediador. In Revista de Processo. vol. 259.p. 471-489. Set. 2016. DTRL2016L22784. Revista dos Tribunais Online.

${ }^{93}$ BRASIL. Lei 13.140, de 26 de junho de 2015. Disponível em: http://www.planalto.gov.br/ccivil_03/_ato20152018/2015/Lei/L13140.htm. Acesso em: 21 jan. 2019.

${ }^{94} \mathrm{O}$ art. $1^{\circ}, \S 3^{\circ}$, da Lei $13.105 / 2015$ dispõe que: "A conciliação, a mediação e outros métodos de solução consensual de conflitos deverão ser estimulados por juízes, advogados, defensores públicos e membros do Ministério Público, inclusive no curso do processo judicial".

95 AWAD, Dora Rocha; TELLES, Marília Campos Oliveira e. Mediação após o Novo Código de Processo Civil e a Lei de Mediação - avanço ou retrocesso? In: Revista de Arbitragem e Mediação, vol. 57/2018. p. 355372. Abr-Jun/ 2018.

96 POMPEU, Renata Guimarães. A mediação nos conflitos familiares: convite ao exercício dialógico da autonomia privada. In: TEIXEIRA, Ana Carolina Brochado; RIBEIRO, Gustavo Pereira Leite (Orgs.). Problemas da família no direito. Belo Horizonte: Del Rey, 2012. p. 104.
} 


\section{Revista IBERC}

v. 2, n. 2, p. 01-35, mai.-ago./2019

www.responsabilidadecivil.org

perdedores, em razão do tempo gasto, da energia consumida, do amargor gerado no íntimo de cada um dos envolvidos. ${ }^{97} \mathrm{Se}$, por um lado, o acesso à jurisdição permite a garantia dos direitos tutelados pelo ordenamento, por outro, permitir a utilização dessa mesma jurisdição como meio de satisfações individuais e privadas advindas de questões exógenas ao direito pode vir a representar um desvio da prestação jurisdicional. ${ }^{98}$

Não se pode negar que a intervenção judicial seja necessária em diversos casos, mas isso não deve ser a regra, mas, sim, a exceção. O direito assumiu hoje, mais do que nunca, um papel transformador, sobretudo de fomento a condutas socialmente desejadas. Essa insatisfação com a abordagem judicial dos conflitos tem identificado os métodos não adversariais como a melhor saída para a "a transformação dos conflitos de forma pacífica para que se resolvam os problemas com menor custo emocional, econômico e social". ${ }^{99} \mathrm{Na}$ busca da melhor solução para o caso concreto, à luz do diálogo e das recíprocas concessões, em vez da substituição da vontade das partes pela imposição do Estado-juiz, a mediação mostra-se, na grande maioria das vezes, muito mais vantajosa. Ao contrário da lógica do ganhar e perder, ínsita aos processos judiciais, a mediação busca que as partes em conflito identifiquem por si mesmas as alternativas do benefício mútuo. ${ }^{100}$

Já há algum tempo, no âmbito dos conflitos familiares e sociais, diversos países promovem políticas públicas efetivas para a promoção e utilização de métodos não adversariais. A formação e a capacitação de mediadores e dos próprios juízes, bem como a advocacia colaborativa ganham cada vez mais espaço no cenário mundial. ${ }^{101}$

\footnotetext{
97 LAGO, Pablo Antonio. O princípio da solidariedade familiar: importância e eficácia. In: TEPEDINO, Gustavo; FACHIN, Luiz Edson (Orgs.). Diálogos sobre direito civil. V. 3. Rio de Janeiro: Renovar, 2012. p. 281.

98 OLIVEN, Leonora Roizen Albek. A judicialização da família. Disponível em: http://portalrevistas.ucb.br/index.php/rvmd/article/ view/2546/1550. Acesso em: 4 jan. 2015.

99 DIAS, Maria Berenice; GROENINGA, Giselle Câmara. A mediação no confronto entre direitos e deveres. Disponível em: http://www.ibdfam.org.br/?artigos\&artigo=42. Acesso em: 8 nov. 2014.

100 Segundo Águida Arruda Barbosa, "no Brasil, a mudança de comportamento, visando a uma nova ética no trato dos conflitos familiares, depende do primeiro profissional que recebe o sujeito do conflito. Culturalmente, recorre-se ao advogado que pode agir como incentivador do litígio, ou pela ética da inclusão, promovendo o encontro dos sujeitos do conflito, ou indicando um mediador" (BARBOSA, Águida Arruda. Educação para mediar; não mais para litigar. Disponível em: http://www.ibdfam.org.br/?boletim\&artigo=293. Acesso em: 10 nov. 2015).

${ }^{101}$ Sobre o tema, v. WEBB, Stuart G.; OUSKY, Ronald. The collaborative way to divorce. Plume, New York, 2007. Na definição do Instituto Brasileiro de Práticas Colaborativas, essas "consistem numa abordagem multidisciplinar, não adversarial e extrajudicial de resolução de controvérsias. [...] Através da manutenção da
} 
A importância da escolha da forma adequada para a resolução de conflitos pode ser demonstrada pela sua crescente adoção por diversos países, como Canadá ${ }^{102}$, França ${ }^{103}$ e Estados Unidos ${ }^{104}$, sendo a mediação a principal prática atualmente adotada. A nova legislação brasileira, embora bastante comemorada, demanda grande empenho para que se implemente uma efetiva mudança cultural, não só dos intérpretes e dos aplicadores do direito, mas da sociedade como um todo. A necessidade de se terem credibilidade e consciência dos reais benefícios trazidos pelos métodos adequados de solução de conflitos por toda a sociedade é essencial para a construção de um novo modelo de justiça cooperativa, colaborativa e democrática.

A imposição de um processo de divórcio à via judicial, por exemplo, sem a tentativa de uma solução via adoção de métodos não adversariais, acaba por inevitavelmente afunilar em excesso as questões em discussão, dando grande enfoque aos reflexos patrimoniais da dissolução, ao passo que o problema existencial por trás da separação do casal permanece ignorado. O resultado é um processo não apenas custoso, como também desgastante e pouco proveitoso às partes. Pelo contrário, em um modelo menos belicoso e colaborativo de resolução de conflitos, como na mediação e nas práticas colaborativas, as relações continuadas têm muito a ganhar, na medida em que não se pretende promover o consenso absoluto entre as partes, mas, sim, possibilitar

autonomia, fomentamos o diálogo produtivo e respeitoso, pautado no espírito colaborativo e na boa-fé, buscando acordos sustentáveis com os quais toda a família possa conviver. [...] As práticas colaborativas oferecem análise e abordagem das situações problemáticas, que favorecem não somente a composição das diferenças interpessoais daqueles que integram esses contextos, mas, especialmente, uma ampliação de habilidades para os diálogos futuros. De grande alcance social, essas práticas cuidam da construção de consenso na vigência das discordâncias, possibilitando, em paralelo, o restauro e a manutenção das relações sociais." Mais informações disponíveis em: http://praticascolaborativas.com.br/home/na-area-de-familia.php. Acesso em: 17 jan. 2017.

${ }^{102}$ No Canadá e na França, onde a prática é desenvolvida há bastante tempo, a mediação não objetiva o acordo em si, este é uma consequência lógica da transformação do conflito pelas mãos dos mediandos, sob o olhar atento e imparcial do mediador (ANDRADE, Gustavo. Mediação familiar. In: ALBUQUERQUE, Fabíola Santos et al. (Coords.). Famílias no direito contemporâneo: estudos em homenagem a Paulo Luiz Netto Lôbo. Salvador: JusPDVM, 2010. p. 494).

${ }^{103}$ A presidente da Comissão de mediação do IBDFAM, Águida Arruda Barbosa, destaca que, "na França, onde a mediação está no plano de excelência tanto de fundamentação teórica como na organização da prática social, as pessoas já conhecem e reconhecem este meio de acesso à justiça e procuram os centros privados de prestação desse serviço especializado. Já houve mudança de comportamento dos jurisdicionados que buscam a justiça doce, como costumam qualificar a mediação" (BARBOSA, Águida Arruda. Educação para mediar; não mais para litigar. Disponível em: http://www.ibdfam.org.br/?boletim\&artigo=293. Acesso em: 10 nov. 2015).

${ }_{104}$ Nos Estados Unidos, a mediação é voltada predominantemente para a resolução de um conflito estabelecido, com vistas a evitar uma demanda judicial e cumprir seu papel de método alternativo de resolução de conflitos, objetivando a obtenção de um acordo (ANDRADE, Gustavo. Mediação... p. 494). 


\section{Revista IBERC}

v. 2, n. 2, p. 01-35, mai.-ago./2019

www.responsabilidadecivil.org

entre elas um efetivo ajuste de condutas de autoria dos próprios envolvidos no conflito, tornando possível o convívio. ${ }^{105}$

O grau de interferência de um terceiro na elaboração de uma solução é, inclusive, uma das essenciais características que distinguem a mediação da conciliação. Isso porque, enquanto na conciliação o objetivo central é a realização de um acordo, na mediação o mediador apenas age como um facilitador, capacitando a comunicação entre as partes sem induzi-las a um consenso. De fato, o mecanismo contencioso não se ajusta a determinados tipos de litígios nos quais se faz mais necessário atentar para os problemas sociais que estão na base da litigiosidade do que para os sintomas que revelam a sua existência.

Assim, a principal característica dos métodos não adversariais é a transformação do conflito em prol da salvaguarda do vínculo entre as partes, bem como a construção de uma "responsabilização mútua pelo sucesso de uma solução, viabilizando parâmetros que tornem possível a negociação futura". ${ }^{106}$ Isso porque, na mediação, em especial, o exercício autônomo de escolha das próprias condutas exige alteridade, isto é, somente pode ser feito diante do outro e em consideração ao outro. ${ }^{107}$ No mesmo sentido, nas práticas colaborativas o consenso é construído com o apoio da equipe multidisciplinar.

A constitucionalização do direito civil e o sistema constitucional de liberdade e direitos fundamentais hoje constitui uma sólida, ainda, que muitas veze negada, referência. O valor principal a ser perseguido no seio das relações familiares é a dignidade da pessoa humana, que só se concretiza nos princípios da liberdade e igualdade, conformados pela solidariedade social.

O protagonismo dos envolvidos nos conflitos familiares e sociais e a mudança de cultura da sociedade com o advento da promoção e utilização dos métodos não adversariais se mostram como um novo modelo de justiça participativa, colaborativa, não

\footnotetext{
105 POMPEU, Renata Guimarães. A mediação nos conflitos familiares: convite ao exercício dialógico da autonomia privada. In: TEIXEIRA, Ana Carolina Brochado; RIBEIRO, Gustavo Pereira Leite (Orgs.). Problemas da família no direito. Belo Horizonte: Del Rey, 2012. p. 105.

${ }^{106}$ RODRIGUES JÚNIOR, Walsir Edson. A prática da mediação e o acesso à justiça. Belo Horizonte: Del Rey, 2006. p.79.

${ }_{107}$ POMPEU, Renata Guimarães. A mediação... p. 109.
}

Revista IBERC, Minas Gerais, v. 2, n. 2, p. 01-35, mai.-ago./2019 


\section{Revista IBERC}

v. 2, n. 2, p. 01-35, mai.-ago./2019

www.responsabilidadecivil.org

interventiva, eficaz e, principalmente, mais democrática. Um resgate da finalidade e do sentido do Direito em busca da pacificação social e da construção da cultura da paz.

\section{REFERÊNCIAS}

AWAD, Dora Rocha; TELLES, Marília Campos Oliveira e. Mediação após o Novo Código de Processo Civil e a Lei de Mediação - avanço ou retrocesso? In: Revista de Arbitragem e Mediação, vol. 57/2018. P. 355-372. Abr-jun./ 2018.

BARBOSA, Águida Arruda. Educação para mediar; não mais para litigar. Disponível em: http://www.ibdfam.org.br/?boletim\&artigo=293.

BARROSO, Luís Roberto. Diferentes, mas iguais: o reconhecimento jurídico das relações homoafetivas no Brasil. Revista Brasileira de Direito Constitucional - RBDC, n. 17, p. 105-138, jan./jun. 2011

BOBBIO, Norberto. Da estrutura à função: novos estudos de teoria do direito. São Paulo: Manole, 2007.

BODIN DE MORAES, Maria Celina. A nova família, de novo: estruturas e funções das famílias contemporâneas. Revista Pensar. Fortaleza, v. 18, n. 2, mai./ago.

BODIN DE MORAES, Maria Celina. A união entre pessoas do mesmo sexo: uma análise sobre a perspectiva civil-constitucional. Revista Trimestral de Direito Civil. Rio de Janeiro, ano 1, v. 1, jan./mar. 2000.

BODIN DE MORAES, Maria Celina. Danos à pessoa humana: uma leitura civil-constitucional dos danos morais. Rio de Janeiro: Renovar, 2009.

BODIN DE MORAES, Maria Celina. Jurisprudência comentada: deveres parentais e responsabilidade civil. Revista Brasileira de Direito de Família. Porto Alegre, n. 31.

CABRAL, Antonio do Passo. CUNHA, Leonardo Carneiro da. Negociação direta ou resolução colaborativa de disputas (collaborative law): Mediação sem mediador. In Revista de Processo. vol. 259.Set .2016. DTRl2016\22784. Revista dos Tribunais Online. 


\section{Revista IBERC}

v. 2, n. 2, p. 01-35, mai.-ago./2019

www.responsabilidadecivil.org

CANARIS, Claus-Wilhelm. Pensamento sistemático e conceito de sistema na ciência do direito. 2. ed. Lisboa: Fundação Calouste Gulbenkian, 1996.

CARBONERA, Silvana Maria. Reserva de intimidade: uma possível tutela da dignidade no espaço relacional da conjugalidade. Rio de Janeiro: Renovar, 2008.

CASTELLS, Manuel. Redes de indignação e esperança - Movimentos sociais na era da internet. Rio de Janeiro: Jorge Zahar, 201.

COHEN, Fernanda. Agressões à pessoa em desenvolvimento: o problema do bullying escolar. Rio de Janeiro: UERJ, Dissertação de Mestrado, 2017.

DIAS, Maria Berenice; GROENINGA, Giselle Câmara. A mediação no confronto entre direitos e deveres. Disponível em: http://www.ibdfam.org.br/?artigos\&artigo=42.

DIAS, Maria Berenice. Manual de direito das famílias. 10 ed. São Paulo: Editora Revista dos Tribunais, 2015.

DONEDA, Danilo. Da privacidade à proteção de dados pessoais. Rio de Janeiro: Renovar, 2006.

FACHIN, Luiz Edson. Famílias: entre o público e o privado. In: PEREIRA, Rodrigo da Cunha (Org.). Família: entre o público e o privado. Porto Alegre: Magister/IBDFAM, 2012.

FACHIN, Luiz Edson. Teoria crítica do direito civil. Rio de Janeiro: Renovar, 2000.

FARIAS, Cristiano Chaves de; NETTO, Felipe Peixoto Braga; ROSENVALD, Nelson. Novo Tratado de Responsabilidade Civil. $3^{\text {a }}$ Edição. Rio de Janeiro: Saraiva, ano 201.

FRANKS, Mary Ann. Criminalizing Revenge Porn: Frequently Asked Questions. Disponível em: https://ssrn.com/abstract=2337998. Acesso em: 18 fev. 2017.

GODINHO, Adriano Marteleto; DRUMOND, Marcela Maia de Andrade. Autoridade Parental e cyberbullying. In: TEIXEIRA, Ana Carolina Brochado; DADALTO, Luciana (orgs). Autoridade Parental: dilemas e desafios contemporâneos. Indiatuba, SP. Editora: Foco, 2019.

HIRONAKA, Giselda Maria Fernandes Novaes. Responsabilidade Civil na relação paterno-filial. Anais do III Congresso Brasileiro de Direito de Família: Família e Cidadania - O Novo CCB e a vacatio legis. Belo Horizonte: IBDFAM/Del Rey, 2002.

JOSSERAND, Louis. Evolução da Responsabilidade Civil. In: Revista Forense, junho/1941. 


\section{Revista IBERC}

v. 2, n. 2, p. 01-35, mai.-ago./2019

www.responsabilidadecivil.org

KONDER, Carlos Nelson. Distinções hermenêuticas da constitucionalização do direito civil: o intérprete na doutrina de Pietro Perlingieri. Revista da Faculdade de Direito (UFPR), v. 60, n. 1, 2015.

LAGO, Pablo Antonio. O princípio da solidariedade familiar: importância e eficácia. In: TEPEDINO, Gustavo; FACHIN, Luiz Edson (Orgs.). Diálogos sobre direito civil. V. 3. Rio de Janeiro: Renovar, 2012.

LÔBO, Paulo Luiz Netto. As vicissitudes da igualdade e dos deveres conjugais no direito brasileiro. Revista Brasileira de Direito de Família. Porto Alegre, v. 6, n. 26, p. 11, out./nov. 2004.

LÔBO, Paulo Luiz Netto. Direito civil: famílias. 4. ed. São Paulo: Saraiva, 2011.

LÔBO, Paulo Luiz Netto. Entidades familiares constitucionalizadas: para além do numerus clausus. Anais do III Congresso Brasileiro de Direito de Família. Família e cidadania: o novo CCB e a vacatio legis. Belo Horizonte: Del Rey; IBDFAM, 2002.

MATOS, Ana Carla Harmatiuk. União entre pessoas do mesmo sexo: aspectos jurídicos e sociais. Belo Horizonte: Del Rey, 2004.

OLIVEIRA, Guilherme de. Queremos amar-nos... mas não sabemos como. Temas de direito da família. Coimbra: Coimbra Editora, 2001.

OLIVEN, Leonora Roizen Albek. A judicialização da família. Disponível em: http://portalrevistas.ucb.br/index.php/rvmd/article/ view/2546/1550.

PEREIRA, Rodrigo da Cunha. O novo divórcio no Brasil. In. PEREIRA, Rodrigo da Cunha (Coord.). Família e responsabilidade: teoria e prática do direito de família. Porto Alegre: Magister/IBDFAM, 2010.

PERLINGIERI, Pietro. O direito civil na legalidade constitucional. Rio de Janeiro: Renovar, 2008.

PERLINGIERI, Pietro. Perfis do direito civil. Rio de Janeiro: Renovar, 1999.

PINHEIRO, Jorge Alberto Caras Altas Duarte. O núcleo intangível da comunhão conjugal: os deveres conjugais sexuais. Revista Brasileira de Direito das Famílias e Sucessões, v. 10, n. 4, p. 104, jun./jul. 2008. 


\section{Revista IBERC}

v. 2, n. 2, p. 01-35, mai.-ago./2019

www.responsabilidadecivil.org

POMPEU, Renata Guimarães. A mediação nos conflitos familiares: convite ao exercício dialógico da autonomia privada. In: TEIXEIRA, Ana Carolina Brochado; RIBEIRO, Gustavo Pereira Leite (Orgs.). Problemas da família no direito. Belo Horizonte: Del Rey, 2012.

RODOTÀ, Stefano. Entrevista. Revista Trimestral de Direito Civil, n. 11, jul.-set. 2002.

RODOTÀ, Stefano. Il problema della responsabilità civile. Milano: Giuffrè, 1967.

RODOTÀ, Stefano. A vida na sociedade da vigilância: $A$ privacidade hoje. Organização Maria Celina Bodin de Moraes. Tradução Danilo Doneda e Luiciana Cabral Doneda. Rio de Janeiro: Renovar, 2008.

RODRIGUES JÚNIOR, Walsir Edson. A prática da mediação e $o$ acesso à justiça. Belo Horizonte: Del Rey, 2006.

SILVA, Marcos Alves da. Da monogamia: a sua superação como princípio estruturante do direito de família. Curitiba: Juruá, 2013.

SCHREIBER, Anderson. Cyberbullying: responsabilidade civil e efeitos na família. Disponível em: http://www.cartaforense.com.br/m/conteudo/colunas/cyberbullyingresponsabilidade-civil-e-efeitos-na-familia/18295.

TAVARES DA SILVA, Regina Beatriz. Reparação civil na separação e no divórcio. São Paulo: Saraiva, 1999.

TEFFÉ, Chiara Spadaccini de. Divulgação não autorizada de imagens íntimas na Internet: - caso da pornografia de vingança. In: BODIN DE MORAES, Maria Celina; MULHOLLAND, Caitlin (Org.). Privacidade hoje: Anais do I Seminário de Direito Civil da PUC-Rio. Publicado em 11 de julho de 2018.

TEFFÉ, Chiara Spadaccini de; BODIN DE MORAES, Maria Celina. Redes sociais virtuais: privacidade e responsabilidade civil. Análise a partir do Marco Civil da Internet. Revista Pensar, Fortaleza, v. 22, n. 1, p. 108-146, jan./abr. 2017.

TEPEDINO, Gustavo. A legitimidade constitucional das famílias formadas por uniões de pessoas do mesmo sexo. Boletim Científico - Escola Superior do Ministério Público da União. Brasília: ESMPU, ano 6, n. 22/23, p. 89-116, jan./jun. 2007. 


\section{Revista IBERC}

v. 2, n. 2, p. 01-35, mai.-ago./2019

www.responsabilidadecivil.org

TEPEDINO, Gustavo. Itinerário para um imprescindível debate metodológico. Temas de direito civil. Rio de Janeiro: Renovar, 2009.

TEPEDINO, Gustavo. Liberdades, tecnologia e teoria da interpretação. Revista Forense, V. 419.

TEPEDINO, Gustavo. A disciplina da guarda e a autoridade parental na ordem civil-constitucional. Revista Trimestral de Direito Civil, v. 17, n. 5, p. 40-41, jan./mar. 2004.

TITO, Karenina. "Infidelidade virtual" - Responsabilidade civil no mundo digital?". In: CALHEIROS, Clara; et al. (Coord.), Direito na Lusofonia. Direito e novas tecnologias. Universidade do Minho. Março de 2018. pp. 239-246.

VILLELA, João Baptista. Repensando o direito de família. Disponível em: http://jfgontijo.com.br/2008/artigos_pdf/Joao_Baptista_Villela/RepensandoDireito.pdf.

VILELA MULTEDO, Renata. Liberdade e Família: limites para intervenção do Estado nas relações conjugais e parentais". Rio de Janeiro: Editora Processo, 201.

WEBB, Stuart G.; OUSKY, Ronald. The collaborative way to divorce. Plume, New York, 2007.

Recebido: 30.01.2019

Aprovado: 02.03.2019

Como citar: MULTEDO, Renata Vilela. Alguns desafios da responsabilidade civil nas relações familiares e as redes sociais. Revista IBERC, Minas Gerais, v. 2, n. 2, p. 1-35, mai.-ago./2019. 